\title{
Comparative constructions of similarity in Northern Samoyedic languages
}

\author{
Nadežda G. Kuznetsova \\ Department of Foreign Languages, \\ Tomsk State University of Architecture and Building \\ nadeshdag@yandex.ru
}

Eleonora Usenkova

Department of Religion and Culture, Interdisciplinary Linguistics Program, University of Saskatchewan

eleonora_usenkova@mail.com

\begin{abstract}
The purpose of this paper is to analyze the suffixes which are used in Northern Samoyedic languages to build comparative constructions of equality. Depending on the language, the suffixes may perform three functions: word-building, form-building, and inflectional. When they mark the noun, they serve as simulative suffixes and are employed to build object comparison. In the inflectional function, these suffixes mark the verb and are a means of constructing situational comparison. In this case, they signal the formation of a special mood termed the Approximative. This paper provides a detailed description of the Approximative from paradigmatic and syntagmatic perspectives.
\end{abstract}

Keywords: modality; evidentiality; comparative constructions of equality; semantics; morphosyntax

\section{Background: Northern Samoyedic languages}

The Samoyedic languages belong to the Uralic family, the largest family in northern Eurasia. According to the conventional classification, the Northern Samoyedic branch includes three living languages: Nenets (Yurak), Enets (Yenisei-Samoyed), and Nganasan (Tawgy). Nenets is spoken along the Arctic coast from the White Sea region to western Taimyr; Enets speakers occupy the territory in the lower Yenisei region; Nganasan is the northernmost language and it is spoken on the Taimyr Peninsula from the lower Yenisei in the west to the Khatanga Bay in the east (Janhunen 1998, 457). All these languages are further split into dialects. Nganasan divides into two very close dialects, Avam and Vadey (Helimski 1998, 481). The Enets dialects are Tundra and Forest Enets. Similarly, Nenets is divided into 
Tundra and Forest Nenets, which in Samoyedology are traditionally viewed as dialects although some scholars, mostly Finnish, prefer treating Forest Nenets as a separate language rather than a dialect, but this is largely a matter of taste and terminology (Helimski 2001, 188).

The morphology of the Northern Samoyedic languages is characterized by agglutination, with suffixation dominant in both derivation and inflexion. There are no prefixes in these languages. The major word classes are nouns and verbs. Verbs and nouns share the categories of number and person. Nouns discriminate the grammatical categories of case (nominative, genitive, accusative, dative, locative, ablative, prolative) and number (singular, dual, and plural). The three types of noun declension are absolute, possessive and (pre)destinative. Nouns also display a set of predicative endings. Verbs are conjugated according to the subjective, objective, and reflexive types. The central category for verbs is mood. The number of moods differs from language to language: 16 moods are mentioned in Nenets (Salminen 1997, 98), 12 moods in Nganasan (Helimski 1998, 503508), and 11 moods in Enets (Mikola 1995, 21), but this list is most likely to be non-exhaustive. The category of tense (aorist/present, past, future) is distinguished only in some of the moods. The set of non-finite forms includes: infinitives, participles, gerunds, and connegative.

In their inflexion adjectives, numerals, and most pronouns do not differ from nouns. Personal pronouns, adverbs, and postpositions comprise minor word classes of their own (Salminen 1997, 91).

Syntacticly, the Samoyedic languages can be characterized as typical SOV languages. Within the noun phrase, the attribute precedes its head. Negation is formed analytically by means of an auxiliary negative verb which takes some derivational and all the inflexional markers, as well as negated lexical verbs in the connegative form.

\section{Comparison by similarity from the general theoretical perspective}

The investigation of the origin, evolution and realization of morphological constructs is one of the major objectives for linguistics. These complex constructs consisting of discrete elements of consciousness - concepts - are known as conceptual categories. As underlying semantic structures, these categories also appear to be a necessary precondition for language functioning and as such are a key subject of study for linguistic typology. Within the limits of typology, systematic comparison of languages allows us to reveal similarities and differences concerning how they express the 
same conceptual categories, and how different languages fulfill the same functional requirements.

The conceptual linguistic category of comparison belongs to the categories of relation as it shows the relationship between referents. It is always an image-bearing reflection of a real situation, which turns into a proposition after all the slots of the relational scheme are filled.

Comparison is subcategorized into two semantic spheres: comparison of inequality and comparison of equality. The former reflects the qualitative aspect of comparison, which means that properties of substances are gradable in terms of degrees of comparison. The latter represents the quantitative aspect of comparison and denotes that substances possess properties that are incompatible with the idea of degrees of comparison. The existence of these two types raises many descriptive issues; however, the comparison of inequality as well as ways of its expression have received by far the best coverage in numerous grammatical surveys from both the perspective of individual languages and crosslinguistically (Andersen 1983; Stassen 1985; Crookston 1994).

Regarding the comparison of equality, most of the relevant linguistic literature claims that it is a non-scalar comparison mostly associated with the semantics of similarity, identity, and sameness (Andersen 1983, 99; Wierzbicka 1996, 72; 143; Haspelmath \& Buchholz 1998, 313; Bužarovska 2005, 74-75; Tommola 2011, 178). Although in essence the given characteristics are entirely valid, the term 'comparison of equality' seems to be too general when describing a particular type of the above-mentioned meanings. Moreover, it is more applicable in the context when describing the gradable comparison of inequality (Andersen 1983, 140; Bužarovska 2005, 75; Haspelmath \& Buchholz 1998, 278; 313). For the reason that in this paper the focus is on similarity, we will further use the term comparison by similarity rather than 'comparison of equality'.

The concept of similarity and the means of its expression in certain languages have been mostly approached by logic, philosophy, and psychology to solve puzzling problems of human cognitive processes (Goodman 1971; Tversky 1977; Sovran 1992). Some of these findings proved to be valuable for linguistics as well. Without entering into the details of a theoretical dispute regarding the nature of similarity, we will outline the fundamental ideas that can be taken as a point of departure when performing semantic analysis of the means of expressing comparison by similarity. Similarity relations are crucial for classifying objects, events, and ideas. These relations demand that the compared entities "be one and the same (in some sense), but at the same time many and different" (Sovran 1992, 336). Serving as an 
organizing classificatory principle similarity helps individuals in acquiring new concepts by expanding "knowledge and language to newly undiscovered areas" (op.cit., 342). Also, in the process of comparison in general, and establishing similarity in particular, special importance is attached to the experience of visual perception. According to Wierzbicka, 'seeing' is a universal human concept since "in all cultures, people are interested in 'seeing' and in describing what they see" (Wierzbicka 1996, 287-289). It has also been assumed that in its genesis, similarity is related, on the one hand, to identification and precision and, on the other hand, to creativity and imagination (Sovran 1992, 342). Identifying compared entities and carefully define their features through seeing predict that similarity is naturally interwoven with the epistemic semantics of veracity of information. The other two concepts - creativity and imagination - underlie the connection between similarity and the interpretation of such creative verbal expressions as metaphors and similies.

There are no languages in the world which lack the means of expressing comparison. In fact, this conceptual category finds its systemic expression in languages on the lexical, morphological, or syntactic levels. Terminologically, in the same way as comparison of equality has been distinguished from comparison by similarity, so it is also convenient to differentiate the means of expression of these types of comparison. It has been suggested that the means of expression of comparison of equality be called equative and those which express comparison by similarity be termed similative (Haspelmath \& Buchholz 1998, 277).

On the lexical level, comparison by similarity is expressed by modal particles and other words which correspond to English like, similar to or to the phrase be like (Bisang 1998, 718). Morphological means encompass both derivational and inflectional forms. Derivational forms widely used for this purpose include affixes, constituents of compound stems, and special elements of unclear status which can be situated between affixes and lexemes (Ralli 2010, 58). In the linguistic literature these marginal elements have been called semi-affixes (Marchand1969 356), semi-words (Scalise 1984, 89), or affixoids (Booij 2010, 57).

The morphological inflectional forms have provoked particular interest and invited many questions. In languages of the world, these forms are associated with a very rare grammatical case which in linguistic literature is known as either 'equative/aequativus' or 'comparative'. This grammatical case belongs to the group of relation cases and is found in languages belonging to various families: Ossetic (Iranian language family; Abaev 1964, 17; Gagkajev 1956, 121), Alutor (Chukotko-Kamchatkan; 
Nagayama 2003, 16-17), Central Yupik Eskimo, (Eskimo-Aleut; Jacobson 1995, 74), Mari and Komi (Finno-Ugric; Alhoniemi 1993, 59; Oszkó \& Ponomareva 2010, 20-22); also, Altaic (Ramstedt 1957, 51-53) and Turkic languages (Menges 1968, 110). '(A)equative'/'comparative' is characterized as being peripheral in the system of grammatical cases, and until now has received little attention on the part of linguists: "the grammars only refer to this phenomenon but do not describe the equative in detail" (Oszkó \& Ponomareva 2010, 20). The descriptions are typically limited to enumerating the corresponding inflexions, presenting the main meaning by formulars 'like (a) N', 'as (a) N', 'such as (a) N', and pointing out that this is a case of adverbial usage. Moreover, a study of the semantic aspect of these cases turns out to be considerably limited because the general notion of comparison is frequently undivorced from its particular semantic realizations such as similarity, identity, and sameness.

On the syntactic level, comparison by similarity is expressed by various comparative-similative constructions. We adopt the viewpoint that a similative construction is a single syntactic whole which contains an obligatory similative component: predicate, turnover, clause, etc. The similative component may have a separate syntactic slot for an index of similative relations in which case the component is per se a syntactic construction. The other possibility is that to express similative relations, the similative construction may have a morphological slot so that the component functions as a morphological construction, although the similative construction on the whole still remains syntactic (Čeremisina 1973, 7).

The prototypical scheme of a similative construction includes the following three basic constituents: (1) the referent/subject of comparison/comparee (the element which is being compared), (2) the agent/ model/standard of comparison (what the comparee is being compared against), (3) the module/basis/parameter of comparison (a feature on the basis of which the comparee is compared with the standard of comparison) (Mezenin 1969, 7; Stassen 1985, 26; Vorobjova 1987, 4; Crookston 1994, 626; Haspelmath \& Buchholz 1998, 279). An obligatory component of a complete comparative construction is an index of comparison which modifies the parameter of comparison (Čeremisina \& Shamina 1996, 66; Dixon 2012, 344-345).

\section{The affixes and their functions}

In the Northern Samoyedic languages there are special suffixes which serve as an index of comparison. They are: -raha-/-laha- in Nenets, -rhaf-/-laha- 
in Enets, and -raku-/-ragu-/-laku-/-lagu- in Nganasan. Historically, they are all descended from a common Samoyedic ancestor (Boldt 1989, 69).

In Northern Samoyedic languages these suffixes may perform the following three functions: word formative, form-building, and inflectional (Labanauskas 1982, 283-284). In defining these types of morphological processes, we will follow the tradition developed by Samoyedological grammar research. Derivation is understood as the process of building the forms of one word, that is, of the unit which possesses one denotative (nominative) meaning and different syntactic meanings. Form-building is the process of creating the forms differing in their nominative grammatical meanings, that is, the meanings of non-syntactic grammatical categories. Finally, inflection is regarded as the process of building the forms which differ only in their syntactic meanings (Živov 1998, 558). Regarding the Northern Samoyedic languages, the first two functions are also briefly described in Tereščenko $(1965,67 ; 1973,206)$. Although in the traditional grammar of European languages the dichotomy between derivation and inflection is widely accepted and often considered the only valid distinction, it is not found to be useful for all languages (Dixon 2010, 218). The differentiation of derivation, form-building, and inflection allows us to specifically approach the morphological means of the three morphological processes and facilitates revealing typological characteristics of the Northern Samoyedic languages.

\subsection{Word formative function}

Our review of the grammars and dictionaries of the Northern Samoyedic languages, as well as examination of the available original texts, reveals that only the Nenets suffix -raha-/-laha-can be used in the word formative function. Examples of such usage are few and are mostly recorded in an academic dictionary of Nenets by Tereščenko (1965). When the Nenets suffix -raha-/-laha-is employed to form new words, it is organically included into the word-stem: $\beta e \beta a-r a h a-m d a\left(s^{\prime}\right)$ 'to put to shame, to embarrass'; $\beta e \beta a-r a h a-m z^{\prime}$ 'to be ashamed, to be embarrassed'; $\beta e \beta a-r a h a-s^{\prime} a\left(s^{\prime}\right)$ 'to be shameless, unblushing', where $\beta e \beta a$ - means 'bad' (Labanauskas 1982, 284; Tereščenko 2003, 67).

\subsection{Form-building function}

According to the Samoyedic linguistic tradition, when the suffixes under consideration are used in the form-building function, they are termed 
similative. In all three Northern Samoyedic languages, the denominative words marked by the similative suffixes convey figurative comparison by similarity. In these constructions, two entities are compared on the basis of a common feature inherent in both of them. As a rule, it is not difficult to identify the lexico-grammatical parallel in these constructions: the comparee has as its own analog - the standard of comparison. The figurative comparative constructions clearly manifest the semantic pattern of comparison: comparee-standard-parameter.

(1) a. Nenets

Сибимчей яля сусахава парграха хоян тэвыни'.

s'ib'imč'ej jal'a susa- $\emptyset-\emptyset=$ haßa

seventh day decline-IND.PRAES-3.SG.S $=$ PRTCL $^{1}$

payg-raha hoja-n te- $\beta$ i-n'if

block-SIMILATIVE mountain-POSS.GEN.1.SG come-IND.PERF-1.DU.S

'By the end of the seventh day we have come to the block-like mountain.'

(Labanauskas 2001, 21)

b. Nganasan

...нербызы хонсуєдеєрєку.

n’erbi-si honsuəd'eə-rəku

fur-POSs.3.sG old bed-SIMILATIVE

'... his fur is like an old bed.

(Lamber 1997)

c. Enets

Дюзє касаруда пизигуо, дирєда энчелха.

d'uz'є kasa-ru-da

ghost brother-LIMIT-POSS.3.SG.ACC

p'iz'i-gu-o- $\emptyset$ d'ir'eda enče-lha

frighten-DUR-IND.PRAES-3.SG.S alive person-SIMILATIVE

'The ghost frightens only his brother, like a living person.'

(Labanauskas 2002, 101)

${ }^{1}$ Abbreviations and symbols in the glosses: 1/2/3: 1st/2nd/3rd person; ABL: ablative case; ACC: accusative case; ADJ: adjective; ALL: allative case; APPROX: the Approximative mood; AUGM: augmentive; CONNEG: connegative; DAT: dative case; DIM: diminutive; DU: dual number; DUR: durative; FUT: future tense; GEN: genitive case; IMP: the Imperative mood; IND: the Indicative mood; INFER: the Inferrential mood; INTERR: the Interrogative mood; LIM: limitative; LOC: locative case; NP: nonperfective; O: objective conjugation; PAST: past tense; PERF: perfect; PL: plural number; POSS: possessive; POSTP: postposition; PRAES: present tense; PROL: prolative case; PRP: present participle; PRTCL: particle; PP: past participle; R: reflexive (objectless) conjugation; RES: resultative; S: subjective conjugation; SG: singular number; TRNSL: translative; VACOND: conditional verbal adverb; VAINF: verbal adverb; VNIPF: imperfective verbal noun; -: morpheme break; =: clitic break. 
As a side note, we should mention that many color terms in Nenets, Enets, and Nganasan are adjectives with a similative suffix in their structure. The examples below illustrate the color term translated as 'green'.

(2) Nenets: நamde?laha 'grass-like', where gamde? is 'grass' (Tereščenko 1982, 214); pad'araha 'bile-like', where pad'a is 'bile' (ibid., 214)

Nganasan: n'otərəku 'grass-like', where n'otə is 'grass' (Kostjorkina et al. 2001, 119)

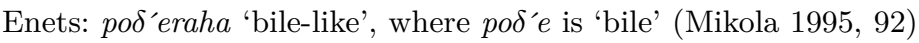

These examples demonstrate that equivalents for the word 'green' in Northern Samoyedic languages are related either to the word 'grass', which is associated with the universal human environment ('things that grow out of the ground'), or to the word 'bile' referring to the near-universal biology of living beings ('fluid, 'juice' produced by the liver of most vertebrates') (Wierzbicka 1996, 306; 308). Despite the fact that the dictionaries provide only one equivalent 'green' for both words, their clear morphological structure suggests that the words denoting the color likened to grass and the color likened to bile are definitely not identical in meaning. At this point, we may loosely assume that the minimal contrast here is connected with the characteristic 'light/dark'. The 'grass-like' green means a light color, whereas the 'bile-like' green may be described as being dark-green to yellowish brown.

Some other examples of color terms formed after the pattern noun plus similative suffix include:

(3) a. Nenets

BLUE: s'unraha 'smoke-like', numlaha 'sky-like', where num is the 'sky'; where s'un is 'smoke' (Kuprijanova et al. 1985, 102)

SCARLET: Bejjaraha 'blood-like', where $\beta \dot{e j j a}$ is 'blood' (Tereščenko 1982, 183)

RED: s'elßraha 'clotted blood-like', where s'elß is 'clotted blood' (Tereščenko 2003, 544)

b. Enets

BLUE: s'udraha 'smoke-like', where s'ud(o) is 'smoke' (Sorokina \& Bolina 2001, 132, 277)

c. Nganasan

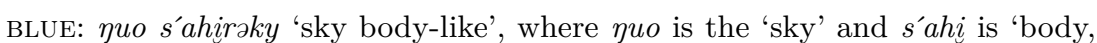
flesh' (Kostjorkina et al. 2001, 138, 248)

GREY: k'intərəku 'smoke-like', where k'intə is 'smoke' (ibid., 64, 344)

BLACK: kularəku 'raven-like', where kula?a is 'raven' (ibid., 72, 371) 
From the data given, it is obvious that all these adjectives are derived from concrete nouns denoting the notions regularly observable by the Northern Samoyedic people in their everyday life. Since the color terms have never been the subject of a special study in Samoyedology, this problem requires careful and comprehensive research in the future.

Specificity of comparative constructions of similarity in Northern Samoyedic languages is due to the fact that they are made by a nominal unit with a comparative component, i.e., the similative affix, and therefore synthetically express a standard and a parameter of comparison.

The semantic structure of comparison could be generally understood as the correlation between the meaning of a comparee and the meaning of a standard (Mezenin 1969, 8). The lexical meanings of the comparison constituents are classified into the following groups:

(4) $X_{1}$ - names of a person or a group of people

$X_{2}$ - names of parts of a human body

$X_{3}$ - names of animals

$X_{4}$ - names of parts of animal bodies

$X_{5}$ - names of mythological creatures

$X_{6}$ - names of elements of inanimate nature and objects

$X_{7}$ - names of substances

$X_{8}$ - names of instruments of labor and their parts

$X_{9}$ - names of weapons and their parts

$X_{10}$ - names of natural phenomena

$X_{11}$ - names of plants and their parts

$X_{12}$ - names of religious attributes

$X_{13}$ - names of various manifestations of animate and inanimate natures

The lexical meaning marked by the sign $X$ with a corresponding numeric notation may belong to both the comparee and the standard of comparison.

In comparative constructions of similarity the standard of comparison is always the bearer of the 'old' information; its deferential features are well known to the native speaker. The deferential features of the comparee (which also is the object of cognition) manifest themselves only in relation to the standard of comparison. Although being different from the comparee, the standard of comparison at the same time shares some common features with the comparee. When two entities are likened to each other, the speaker chooses the most significant one from among the deferential features - the feature inherent in both the comparee and the standard of 
comparison. It is this feature that structurally serves as the parameter of comparison and ontologically enables the speaker to open new qualities in the comparee in order to show the comparee in a different perspective.

By the nature of the chosen quality, the differential features could be classified into the following types:

1. Qualitatively-defining features which denote various physical qualities of the object.

(a) Shape

(5) a. Nenets

Тад уоб таняхуна нибяраха сохоя нимня падимя.

tad nob tan'a-huna n'ib'a-raha

then suddenly here-LOC.SG needle-SIMILATIVE

sohoj-a n’imn'a

high.pointed.bald.mountain.with.a.wide.base-AUGM under

nad'im’a- $\emptyset-\emptyset$

come.into.view-IND.PRAES-3.SG.S

'Then he has suddenly found himself here at the pointed bald needle-like mountain with a wide base.'

(Labanauskas 2001, 127)

b. Nganasan

Нерәны" мәнурәку дига"ку уәтумы"ә.

n'erəni? mənu-rəku d'iga?-ku

in.front.of egg-SIMILATIVE mountain-DIM

nətumi-ใə- $\emptyset$

come.into.sight-IND.PERF-3.SG.S

'He has found himself in front of the mountain which looks like an egg.'

(Tereščenko 1979, 109)

c. Enets

Эбар козэда лохи эбараха.

eba-r kozeda loh'i eba-raha

head-POSs.2.SG shaggy tussock[-GEN] top-SIMILATIVE

'Your head is shaggy like the top of the tussock.' (Sorokina \& Bolina 2005)

(b) Appearance and external manifestations

(6) a. Nenets

Нумлаха то"я' сидяда сё"яда.

num-laha to?-ja-f s'id'a-da s'o-?ja-da

sky-SIMILATIVE lake-AUGM-GEN.SG two-POSS.3.SG channel-AUGM-POSS.3.SG

'The lake which looks like the sky has two channels.' (Tereščenko 1990, 123) 
b. Nganasan

тыбийкиа анігє, тыбийкагкурєкы

tib'ijk'ia an’igə tib’ijka-gku-rəki

boy big boy-DIM-SIMILATIVE

'a big boy like a small boy'

(Daniel \& Gusev 2003)

c. Enets

Дёа дяра иблег незараха.

d'oa d'ara-a- $\emptyset$ ibl'eg n'e-za-raha

Dyoa cry-IND.PRAES-3.SG.s little child-POSs.3.SG-SIMILATIVE

'Dyoa is crying like a little child.'

(Sorokina \& Bolina 2005)

(c) Color

(7) a. Nenets

Енко уэвада теда' уадимдана яля' нярмраха.

jen-ko neßa-da t'edafy nad'imda-na

hemp-DIM head-POss.3.SG now appear-PRP

jal'a-f n’arm-raha

day-GEN.SG reddish.color-SIMILATIVE

'Her head of the hemp color is now like the reddish color of the appearing day.'

(Tereščenko 1990, 43)

b. Nganasan

Тєндє дикарага нииде тахариабє неначагку тєсиєsє нёрумує

корузагагўмўрє тахариаиг њануємєны сильби дюкєрєкы тє.

təəndə d'ikara-ga n'iid'e tahar'iabə

that [-GEN] mountain-AUGM[-GEN] alongside now

nenač'ag-ku təs'iəsə n'orumu-ə korusa-ga-g'um'u-rə

huge-DIM now brass-ADJ house-AUGM-AFFIRM-POSS.2.SG

tahar'iaig nanuə-məni s'il’b'i d'ukə-rəki tәə

now real-PROL blood.clot[-GEN] piece-SIMILATIVE indeed

'On the side of the mountain now there is a huge brass house, indeed it is red like a piece of blood clot.'

(Lamber 1997: Djajku)

c. Enets

Чихи деон няба сырную сылейг сырараха.

č́ih'i d'eon n’aba sirnuju sil'ejg sira-raha

this for purpose hare in winter white snow-SIMILATIVE

'And this is why a hare in winter is white like snow.' (Sorokina \& Bolina 2005) 
(d) Quality of the substance

(8) a. Nenets

Сян" ербата памзада и"лаха.

s'an-? jerba-ta yamza-da ip-laha

however.much-GEN rip-PRP carcass-POSS.3.SG water-SIMILATIVE

'No matter how much I am ripping [the giant], his flesh [flows together] like water.'

(Tereščenko 1990, 47)

b. Enets

Чикир бэсэрха чида сама єза.

čik'i-r bese-rha č́i-da sama $\varepsilon$-za- $\emptyset$

this-POSS.2.SG iron-SIMILATIVE fly-PRP animal be-PRAES-3.SG.S

'Your friend will be an iron-like bird.'

(Labanauskas 2002, 97)

(e) Stability

(9) Nenets

Мань нэкалпа'на вэсы сюдбяр переня салраха.

man' nekal-pa?-na Besi s'udb'a-r p'er'e-n'a

I seize-VACOND-POSS.GEN.1.SG old athlete-POSS.2.SG hold.oneself-PRP

sal-raha

stub-SIMILATIVE

'When I seize [him], the old athlete holds himself like a stub.' (Tereščenko 1990, 127)

2. Functional features which indicate the intended use of the objects.

(10) a. Nenets

Вэнеку манма: «Ервхаюни таняуаха'. Сидя нярава сядэйха’ - няби хасаварха няби нерха.»

Ben'eku man $=m a=\emptyset-\emptyset \quad$ jer $\beta$-haju-n'i

$\operatorname{dog} \quad$ say $=$ PRTCL $=$ IND.PRAES-3.SG.S master-DU-POSS.1.SG

tan'a- $\emptyset$-nahaf $\quad$ s'id’a n’araßa s'adej-haf

have-IND.PRAES-3.DU.S two brass idol-DU

n’ab'i hasaßa-rha n’ab'i n'e-rha

one man-Similative the other woman-SIMILATIVE

'The dog says, "I have two masters. Two brass idols - one [of them] is like a man, the other is like a woman".

(Labanauskas 2001, 123)

b. Enets

Бу’ уйза нэ уйраха эбидь.

bu-f uj-za ne uj-raha e-b'i-d'

he-GEN breast-POSS.3.SG woman breast-SIMILATIVE be-IND.PERF-3.SG.R

'His breast was like the breast of a woman.'

(Sorokina \& Bolina 2005) 
c. Nganasan

Коуту динді? ә, Коубтуму пуә раадивәрәку.

kou-tu d'ind'i-?ә- $\emptyset$ koubtumu nuə raad'ivə-rəku

ear-POSS.3.SG hear-IND.PERF-3.SG.S Koubtumu god radio-SIMILATIVE

'His ear has heard it, god Koubtumu is like the radio.' (Helimski 1994, 62)

3. Quantitative features which indicate the quantity of the objects.

(11) Nenets

Няби хэвхад яраха" саюв" тауомы яраха.

n’ab'i heß-had ja-raha-? sajuß-? tayo-mi ja-raha

other side-ABL.SG earth-SIMILATIVE-PL force-PL summer-PP earth-SIMILATIVE ${ }^{2}$

'From both sides the earth-like forces of enemies are similar to the summer earth.'

(Tereščenko 1990, 126)

\subsection{Inflectional function of the affixes}

In the Northern Samoyedic languages, comparison of two discrete entities (the object comparison) is opposed to comparison of more or less expanded situations (the situational comparison). Both types of comparison have a similar logical structure. The difference between them is that in the case of object comparison the analyzed suffixes mark the noun, whereas for situational comparison they mark the verb. When these suffixes are added to the verbal stem, they perform the inflectional function. The situational comparison by similarity can be rendered with the help of the phrases 'seem to be like', 'it seems that/as if', and 'it looks like/as if'.

(12) Nenets

a. Хэвхананта сив хэхэ уамчувы. Малуэ ту лэюраха".

heß-hana-nta s'i $\beta$ hehe

side-LOC.SG-POSS.3.SG seven hehe-hehe (guardian-spirit)

yamč́u- $\beta$ i mal-yə tu leju- $\emptyset$-raha-?

sit-PP all-TRANSL fire flare.up-PRAES-APPROX-3.PL.S

'By his [heavenly father's] side seven guardian-spirits are sitting. They are all as if the fire is blazing.'

(Labanauskas 2001, 115)

\footnotetext{
${ }^{2}$ The word 'earth' is used to mean a very large number of forces that cover all the sweep of vision.
} 
b. Мята мюй мал турха.

m’a-ta m’uj mal tu-rha

tent-POSS.3.SG inside all fire-SIMILATIVE

'His tent inside is all like fire.'

(ibid., 128)

In the available works devoted to Northern Samoyedic grammar, the verbal forms marked by the affixes under study have received different status and names.

In the grammatical publications based on the Nenets language, the forms marked by the suffixes -raha-/-laha- are relatively unanimously given the status of a verbal mood. Castrén believes that -raha-/-laha- are the marker of the Optative mood: "Dieser Modus, der nur im Jurakischen verkommt, zeichnet sich durch der Charakter rawa, lawa aus: z.B. tôrawa, er möchte (würde) kommen, adlawa, er möchte (würde) schinden. Wie die Syntax näher nachweist, ist dieser Modus seiner Bedeutung nach etwas unbestimmt und was die Etymologie betrieft, so bin ich nicht im Stande eine befriedigende Erklärung des seinem Aussehen nach zusammengesetzten Charakters zu geben" (Castrén 1854/1969, 370). Sebestyén also considers -raha-/laha- to be the markers of mood, although not Optative but Precative, and associates their origin with the verbal noun: "Eigentlich ist der Prekativ auch ein Verbalnomen, dessen Suffix dadurch entstanden ist, dass das Suffix *ka, *ke mit dem intensiv-effektiven Suffix $-r$ verbunden wurde" (Sebestyén 1970, 214). In this connection Künnap notes that the first elements of these affixes -ra-, -la- seem to be identical with the markers of the Optative: "Auf jeden Fall scheint die Anfangskomponente dieses Zeichens - ra-, -l'a- mit dem jenisseisamojedischen Optativzeichen -ra, laz.B. to/ra 'käme er doch' - identisch zu sein" (Künnap 1978, 104-105).

In grammars of Nenets, this mood is listed under various names, such as the Comparative mood (Boller 1857, 262), the Suppositional mood (Verbov 1973, 99), the mood of a Seeming Action (Labanauskas 1982, 283; Burkova 2004, 367), the Approximative mood (Salminen 1997, 98), the Similative mood (Ljublinskaja \& Maljčukov 2007, 449).

In Enets, forms with the suffix -rhaf-/-rha-/-laha- have been treated as a mood in the works of Labanauskas, where they were mentioned as the Second Suppositional mood (Labanauskas 2002, 56) and by Mikola, who termed these verbal forms as Probabilitive 1 (Mikola 1995, 21).

In Nganasan, the morphemes -raku-/-ragu-/-laku-/-lagu-are not found in the inflectional function and for this reason they are mostly regarded as form-building suffixes commonly known as similative (Tereščenko 1979, 140; Boldt 1989, 68) or comparative (Gusev 2007, 442). The only two examples provided by Tereščenko $(1973,143)$ cannot be considered forms 
of the verbal mood since they illustrate the use of the participles in the predicate function.

(13) Nganasan

а. Кундуатуорәгур.

kundua-tuo-rəgu-n

sleep-PRP-SIMILATIVE-2.SG.S

'It looks like you are sleeping.'

(Tereščenko 1973, 143)

b. Тәнә тумтәтуорәгум.

tənə tumtə-tuo-rəgu-m

you [-ACC] remember-PRP-SIMILATIVE-1.SG.S

'It looks like I recognized you.'

(idem.)

\subsubsection{Terminology}

In the Samoyedic languages, verbal moods are mostly a morphological means of expressing modality, but sometimes they also express evidentiality. When this is the case, we speak of evidential moods. Evidentiality is defined as a linguistic category whose primary meaning is the source of information (Aikhenvald 2006, 320). It is a verbal grammatical category in its own right and it does not bear any straightforward relationship to truth, the validity of a statement, or the speaker's responsibility (idem.). "It is not a subcategory of any modality, or of tense-aspect" (ibid., 7). The most general classification of evidential meanings is based on the distinction of direct (visual and non-visual) and indirect (inferred and reported) evidentials (De Haan 2008). For an exhaustive cross-linguistic typological study of evidentiality, see Aikhenvald (2004).

The modern literature unanimously recognizes that modality has become one of the most challenging areas of linguistic studies in recent years. However, despite the current flurry of publications devoted to modality, this notion has not yet received a generally accepted definition which exhaustively embraces all its aspects. The extreme standpoints on modality are boiled down to understanding it in a narrow sense as "the area of meaning that lies between yes and no - the intermediate ground between positive and negative polarity" (Halliday 1985, 356) and in a broad sense as "the attitude of the speaker to what he is saying" (Bublitz 1978, 6-9). Difficulties associated with defining modality, as well as classifying and describing the realization of various modal meanings, constitute only a particular case of a multifaceted problem of modality, the problem that goes far beyond the scope of linguistics. Modality has been an object of intensive research not only by linguistics but also by other scientific disciplines, such as logic, philosophy, and psychology. The interdisciplinary 
efforts have inevitably triggered an active exchange of new discoveries and original ideas among linguists. They have caused a significant divergence in the theoretical understanding of modality and in the evaluation of its status in language status and semantic scope. In typological and functional linguistics, the groundwork was laid by Palmer (2001) and Auwera and Plungian (1998), scholars who contributed to the collection of papers in Bybee \& Fleischman (1995) and Givón (2001). In formal semantics the most influential works are Wright (1951); Kratzer (1981), and Portner (2009). The investigation of modality in cognitive linguistics is based on the works of Mortelmans (2007) and Nuyts (2001). In philosophy of language, the problems of linguistic modality are targeted in the works of Lewis (1985) and Devitt \& Sterelny (1999).

In addition to the above problems, within the framework of linguistics itself there exist serious difficulties connected with establishing and describing modality as a cross-linguistic grammatical category. The main "stumbling blocks" frequently mentioned in linguistic literature are the absence of a single semantic feature with which modality may be correlated, the notoriously vague and often diffuse semantics of the modal systems in different languages, and the subtle and endlessly intricate empirical details (Palmer 1999, 229; Barker \& Kennedy 2009, xi). Moreover, a sophisticated structure of modality can be expressed by a wide variety of its means of expression which are found at all the linguistic levels (phonetic, lexical, lexico-syntactic, and syntactic) and often do not coincide from language to language.

Another important issue raised in the literature concerns the distinction between 'modality' and 'mood'. Being expressed by linguistic means modality becomes a grammatical category. And, just as there exist bitter theoretical debates about the essence of modality, so too there exist debates about the essence of mood. Traditional linguistic studies often note that mood overlaps with modality and that semantically they are not opposed to each other. This gives the grounds to use the two labels interchangeably in some languages (Plungjian 2003, 309; Bauer 2004, 69). As Kiefer observes, some linguists make a distinction between 'sentence mood' and 'verbal mood'. The former is understood as a semantic category, the modal value of sentence types whereas the latter is viewed as a morphosyntactic category (Kiefer 1999, 224; Davidsen-Nielsen 1990; Akmajian et al. $2010,591)$. Also, there is a point of view according to which mood is not one, but a set of morphological categories that express a speaker's degree of commitment to the expressed proposition's believability, obligatoriness, desirability, or reality (Aronoff \& Fudeman 2011, 266). A radically different 
approach is put forth by Mel'čuk (1998) who treats modality and mood as two unconnected categories.

Despite all these controversies, the classical definition of mood is based on the facts that it is "a purely morphological category of the verb" (Palmer $1999,229)$ and that "what is covered by mood may differ from one language to another" (Bauer 2004, 69).

In this paper, we will regard modality as a multifold notional category which covers the following semantic aspects:

(i) Internal modality is the relationship of the subject/object of the action to the performed action; for the object it is the relationship to the action which it undergoes. This type of modal relationship reflects an assessment of the connection between the subject/object of factuality and the feature assigned to it from the point of view of the mode of existence of this relationship: whether that be possibility, necessity, or desirability.

(ii) External objective modality is the relationship of the sentence content to factuality in the plane of reality/irreality. This type of modality is an obligatory characteristic of any utterance. It is one of the categories that forms a predicative unit - a sentence.

In the system of moods, real actions are those which not only were performed or are being performed within a designated period of time, but also are actions, the reality of whose performance is possible, necessary, desirable (internal modality), or only supposed (elements of irreality).

The core of reality is actuality. It reflects the existence which does not contain elements associated with such modal meanings as irreality, potentiality, unreliability, somebody else's experience, etc. The meaning of actuality finds its immediate expression in the situation of the Actual Present, which is the situation ' $\mathrm{I}$ - now - here - this'. The Actual Present denotes the highest degree of reality, i.e., experienced, perceived, concrete, and evident (Bondarko 1990a, 72).

Irreality/hypotheticality denotes - from the point of view of the speaker - a supposed action which in a particular context acquires various modal and expressive-emotional overtones: wish, encouragement, contrition, etc. The conditional character of performing this action - that is, dependence on some conditions, causes, situations - is implied, but is not expressed by lingual means (Šentsova 1998, 35-37). The action is spoken of as if it existed in factuality but only conditionally. If the sentence contains a definite condition, cause, or situation the action is interpreted as being real (Ermolaeva 1987, 70).

Irreality is connected with reality through the sphere of potentiality, which includes unreality; because of this connection between reality and 
irreality in their qualitative distinctness there exist gradual transitions. In general, potentiality denotes the ability of a situation or thing 'to be not what it is', i.e., the ability to be changed from the point of view of substance, quality, quantity, place, time, and some other factors (Bondarko 1990a, 75). The integral meaning of potentiality covers various categorial meanings of external objective modality (imperativity, optativity, hypotheticality, conditionality) and external subjective modality (possibility, necessity, reliability, obligatoriness, intentionality), and can accompany the utterances of different communicative types.

Unreal actions are actions that either were not performed or are not being performed within a designated period of time-implied negation is an objective factor, but these actions are spoken about in a conditional manner: as if they had been performed or were being performed-i.e., absence of direct indication of negation.

(iii) External subjective modality combines the meanings of external objective modality and the assessment of an utterance by its originator. The semantic components of this modality - reliability, possibility, probability, obligatoriness, intentionality, and evaluation of the trustworthiness of information - supplement the basic characteristics of external objective and communicative modalities. External subjective modality also includes the notion of assessment as well as various kinds of emotional (irrational) reaction.

(iv) Communicative modality covers the meanings of declaration, interrogation, and inducement.

(v) Emotive modality deals with expressive/non-expressive utterances. Emotivity expresses subjective reactions of the speaker and as such is closely connected with expressivity and assessment.

Crosslinguistic studies of the grammatical category of mood prove that any of these five aspects of modality can be expressed by morphological means. This explains why the semantics of this category is not identical in different languages (Ermolaeva 1987, 12). In view of the fact that different sets of the aforesaid types of modality may be expressed by different formal means, the definition of the category of mood should be quite broad and allow concretization in particular languages in different periods of their developments. Therefore, we define mood as "an inflectional category of the verb that can express any of the above-distinguished aspects of modality" (Kuznetsova 1995, 73; Kuznetsova \& Usenkova 2003, 266). 


\subsubsection{The paradigm of the Approximative}

In our description, the regular paradigm of the Approximative in Nenets and Enets is built on the opposition of three persons $(1,2,3)$, three numbers (singular, dual, plural), three types of conjugation (subjective, objective, objectless/reflexive), and includes the personal endings common for all the moods. The Approximative is realized in one of four tenses: present, past, perfect, future. The place of the Approximative suffix in a word depends on the structure of the tense affixes and will be described at length further in section 3.3.5.

\subsubsection{The paradigmatic meaning of the Approximative}

The paradigmatic meaning of the Approximative is external objective modality of irreality complicated by the meaning of subjective visual perception. In this meaning the Approximative is used in declarative descriptive sentences of irreal comparison.

Sentences with the situational comparison have a remarkable peculiarity: if the comparee denotes the situation in the most generalized sense it is not verbalized and, thus, the sentence contains only the standard marked by the Approximative suffix. This generalized situation may be associated with various existential, behavioral, physiological and psychological states. It is uncontrolled in the sense that the subject-agent does not intentionally perform the action, the result of which does not coincide with the object of intention and which is regarded as being not determined by the preceding action (Zaliznjak 1992, 64). As a rule, the perceiving subject lends a generalized character to the situation because the context makes it self-evident.

(14) Nenets

Тад сыла уани’ ик' марць' нимня Фарка уаядал не' мэта иняхана сякаладараха.

tad sila- $\emptyset-\emptyset \quad$ yan'if ik- $f$

then look-IND.PRAES-3.SG.G again neck-GEN.SG

marc'-f n'imn'a yarka najadal n'e- $f$

shoulder-GEN.SG over elder monkey woman-GEN.SG

meta in'a-hana s'akala-da-raha- $\emptyset$

used strap-LOC.SG bite-PRAES-APPROX-3.SG.S

'Then she [woman] looked again over shoulder, the Elder monkey seemed to be biting a woman's rein.'

(Tereščenko 1990, 196)

In fact, the sentences of irreal comparison demonstrate the relations of causality rather than similarity. The semantic structuring of the forms 
marked by the Approximative may be represented by the following two stages.

In the first stage, a real situation causes the speaker's opinion which is rendered by the words 'the impression is gained that...'

(15) Nenets

Мэдаркана не тарцяри вадарим' уатевэкораха, пин' ти тибтидей".

medarkana n'e tarc'a-r'i ßada-r'i-mf

limping woman such-LIMIT speech-LIMIT-ACC.SG

yat'eßeko- $\emptyset$-raha- $\emptyset$ p'in- $9 \quad$ t'i t'ibt'id'ej- $\emptyset$-?

wait-PRAES-APPROX-3.SG.S street-DAT.SG here step.outside-IND.PRAES-3.SG.R

'A limping woman seemed just as if she was waiting for such words [the impression

is gained that a limping woman was waiting for such words], she stepped outside.'

(Tereščenko 1990, 60)

In the second stage, the semantic representation of a comparative construction allows two interpretations: (1) a real situation causes a goal which is interpreted by the perceiving subject as follows: an irreal situation exposes the inner essence of a real situation, or (2) a real situation causes an impression that there is a causative connection between it and another situation. The second way of reading the semantic representation becomes possible due to the fact that the goal can be regarded as an intrinsic motive.

(16) Nenets

Ламдик ёнэй уэварида яры. Пыда мантараха: «Не начекы, тарем тась харвава̄бат, тахав».

lamd'ik jonej neßa-r'i-da jari- $\emptyset-\emptyset$

Lamdik middle head-LIMIT-POSS.3.SG turn-IND.PRAES-3.SG.S

pida man-ta-raha- $\emptyset$ n'e načeki tar'em

he say-PRAES-APPROX-3.SG.S woman child so

ta-s' harßaßā-bat ta-ha- $\beta$

bring-VAINF wish-VNIPF give-IMP-1.SG.S

"The middle son of Lamdik has only turned his head, it was as if he was saying,

"Young girl, if this is your wish, I will do this."'

(Labanauskas 2001, 93)

\subsubsection{The meaning of 'seemingness'}

Besides the semantics of irreality and implied conditionality, the paradigmatic meaning of the Approximative contains the comparative component which imparts to the constructions of irreal comparison of equality (similarity) a strong subjective character and signals the presence of the speaker. Situations modeled by comparative constructions are an object of mental processing, namely, an object of perception, knowledge, and evaluation. 
Comparative constructions can be as diverse as the perceptions of the world by different speakers are. Hence, the utterances of irreal comparatives are characterized by the subjectified manner of reporting information, because the 'relationship of similarity already brings modal connotations' (Gisborne \& Holmes 2007, 21).

Due to the meaning of subjectivity expressed by comparatives, the Approximative expresses external subjective modality, in particular, the semantics of 'seemingness' which is defined as subjective impression or subjective perception (Semjonova 2004, 151). In general, seemingness integrates in its semantics the modal meaning of subjectivity and the evidential meaning of visuality. In Nenets and Enets, the Approximative forms are employed when the observer obtains direct visual information about the real state of things, but for some reason does not trust this information (Bulygina \& Šmeljov 1993, 80). It follows that the semantics of 'seemingness' favours the formation of 'uncertain reports'. Uncertainty of the speaker in the veracity of the situation is connected with the feature of 'sufficiency/insufficiency' of the information which provides the quantitative assessment of the available information and the degree of its veracity (Ioanesân 1993, 94).

(17) a. Nenets

Dарка Вай мякад уадимя, ма: «Ептов, амгэм манэуанэй"?» «Тайна ханъяда пэрха». yarka $\beta$ aj m'a-kad nad'im'a- $\emptyset-\emptyset$ ma- $\emptyset-\emptyset$

elder Vaj tent-ABL.SG appear-IND.PRAES-3.SG.S say-IND.PRAES-3.SG.S

jepto $\beta$ amge-m mane-na-ne-j? tajna hanjada

brother what-ACC.SG see-ya-PRP-POSs.1.DU there catch

ye- $\emptyset$-rha- $\emptyset$

be-PRAES-APPROX-3.SG.S

"The elder Vaj has come out of the tent and said, "Brother, what do you see?"

"It seems that there is a catch [rein-deer] there".' (Labanauskas 2001, 85)

b. Enets

Куто̄хинэ инэни но со̄мобизо. Тэйно озизарха, фуадо тэйно модяра̄би.

kutōh'ine ine-ni n’i sōmo-b’i-zo

from.time.to.time elder.brother on cast.a.glance-PERF-1.SG.S

tējno oz'i-za-rha- $\emptyset$ fuado tējno mod'arā-b'i- $\emptyset$

so appear-PRAES-APPROX-3.SG.S all.the.time so work-PERF-3.SG.S

'Occasionally I cast a glance at my elder brother. So it seems as if he is working so all the time.'

(Labanauskas 2002, 136)

The criterion of veracity means that the information gained visually is ranked highest in the hierarchy of information types. It is followed by information obtained through other sensory (but non-visual) perception. 
Next in the hierarchy is context-dependent information, i.e., the description of the logical inference based on indirect evidence. Second-hand information occupies the next, lower, level. At the bottom of the hierarchy is context-independent information (Ioanesân 1993, 94).

Expressing the meaning of 'seemingness', the Approximative implies that the situation is perceived visually; the observer is in direct contact with the situation under evaluation. Hence, the Approximative describes events the probability of whose realization is high. At the same time, these situations could be characterized by problematic reliability inasmuch as impediments during perception prevent the observer from obtaining sufficient information (Beljaeva 1990, 165-169).

So far, the sensory nature of the Approximative has not received due attention and clear interpretation in Samoyedology. Only a passing mention is made in recent descriptions of the Nenets evidentials: the Approximative may express an 'impressive' meaning understood as uncertain evaluation of the veracity of information obtained through direct perception (Burkova 2004, 370; Ljublinskaja \& L. 2007, 451). It is obvious that this observation of direct sensory (visual?) experience strongly speaks to the interpretation of the Approximative as a specific direct knowledge evidential, which could be called 'uncertain visual'. Regarding the visual, in Nganasan, there is a viewpoint that the evidentiality system is based on the opposition of an unmarked visual versus other marked evidentials. The former is expressed by the forms of the Indicative, Interrogative, and other non-evidential moods whereas the latter are expressed by special evidential moods (Gusev 2007, 417). The possibility of a language to display two types of the visual - an unmarked visual and an uncertain visual - is rarely reported in typology (Palmer 2001, 50), and it is quite questionable. Therefore, we share the opinion that the unmarked situation cannot be regarded as an evidential. "If the verb is unmarked for evidentiality, it may refer to visual information, but it does not have to. This interpretation is consistent with a general tendency for information acquired visually to be less formally marked than the information acquired through any other source" (Aikhenvald 2004, 50).

(18) Nenets

[Тикы' тарця уэсь мят' ханя тю', тэри та' монэй".] Хасава манма: «Тикэхэвар

ненэцяргава уэдараханё, тюку’ мэдва!»

hasa $\beta a$ man $=$ ma $=\emptyset-\emptyset \quad$ t'ike $=$ he $\beta a=r$

man $\quad$ say $=\mathrm{PRTCL}=\mathrm{IND} . \mathrm{PRAES}-3 . \mathrm{SG} . \mathrm{S}$ this $=\mathrm{PRTCL}=\mathrm{POSS} .2 . \mathrm{SG}$ 


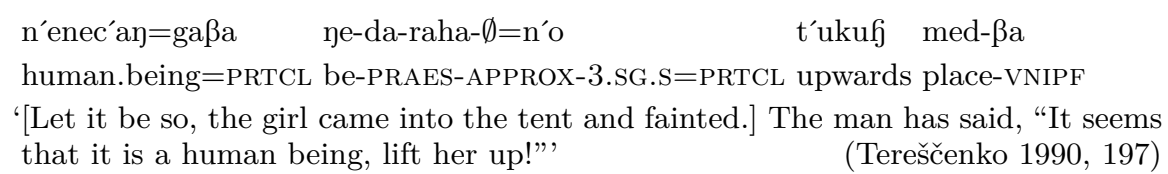

In situations of uncertain visual perception described by the Approximative, the notion of observability plays a key role. In a broad sense, observability also could be understood as the property of an object of a real or semblant (existing in senses, memory, imagination, etc.) situation to be perceived at a definite moment of time. The perceiving subject and the perceived object are connected by the perceptual act: in absence of one, the other cannot exist. The subject perceives an object by vision only when it is within sight; the object is perceived only when there is a perceiving subject who is either adjusted to perception or involuntarily perceives the object. The act of perception is dynamic. It proceeds at a definite time and is conditioned by both the degree of adjustment of the subject's perceptive system (efforts, attention, eye movement, etc.) and by environmental conditions ('density' of the environment, illuminance, availability of optical instruments to strengthen visual ability, etc.).

Visually perceived characteristics of the object are categorized by the perceiving subject as manifestations of the subject's emotional states. When performing mental activity, the perceiving subject functions simultaneously as the observer and the knower. However, the perceived object by itself is not the carrier of necessary information. A human gives the object informational significance only after the perceived entity enters into definite relation with the observer's knowledge and experience.

(19) Nenets

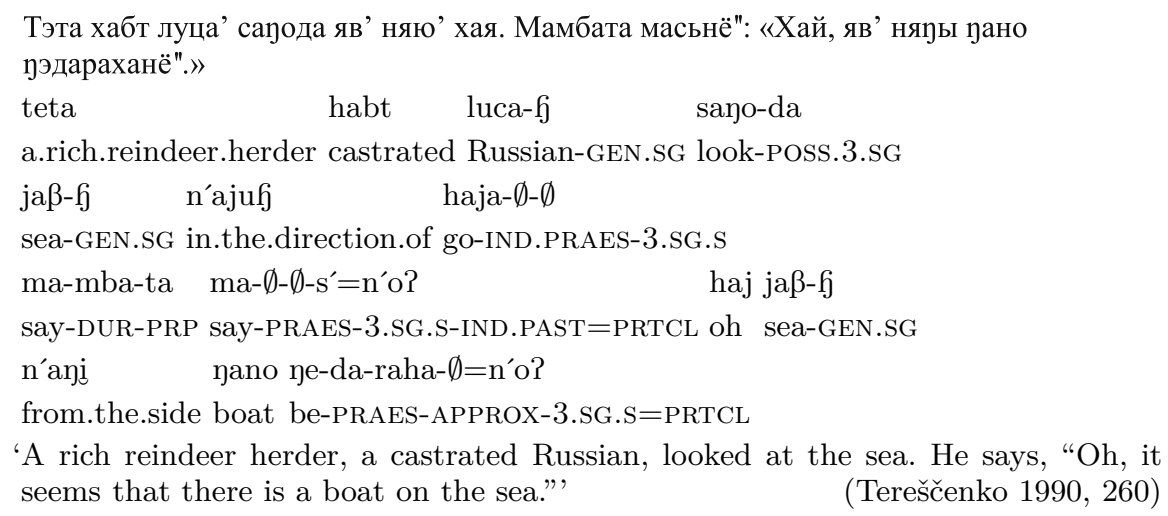


The meaning of 'seemingness' has an ontological foundation: since reality reflected in language is complicated and multi-faceted, a human's knowledge about reality is incomplete. One of the factors that conditions the origin of this meaning is - as mentioned earlier - 'impediments' in perception. These impediments may be connected with both functional and psychological states of the perceiving subject - hearing sensitivity, poor memory, fatigue, overexcitement - as well as with conditions of the environment such as, for instance, unwanted sounds or distorted, unclear, and not quite loud acoustic signals.

(20) a. Nenets

Мань няюни не ёргамъя"нё, нена" нябакоми уэвыдарханё.

man' n'aju-n'i

n'e

I in.the.direction.of-POSS.GEN.1.SG woman

jongamja- $\emptyset-?=$ n'o $^{\prime} \quad$ n'ena?

look.back-IND.PRAES-3.SG.R=PRTCL too much

n'abako-m'i neßi-da-rha- $\emptyset=$ n'o

elder.sister-POSS.1.SG be-PRAES-APPROX-3.SG.S $=$ PRTCL

'When she looked back at my side, it seemed to me that she resembled my elder sister too much.'

(Tereščenko 1990, 238)

b. Enets

Накую мякон каяй каса нида Дёнайку эзарахаби.

nakuju m’a-kon kaja-j kasa

other tent-LOC stay-PP brother

n'i-da d'onajku e-za-raha-b'i- $\emptyset$

name-POSS.2.SG Dyonaku be-PRAES-APPROX-PERF-3.SG.S

'The other brother who stayed in the tent seemed to be known by the name Dyonajku.'

(Sorokina \& Bolina 2005)

In the context of impeded perception, the perceived entity may be illdefined. As a result, its image is composed of many small features. Moreover, paralinguistic signals of the perceived entity may not always be decoded and interpreted precisely; there may be differences in interpreting the relations which connect the emotional state of the perceived entity (person) with the external expression (Semjonova 2004, 152).

(21) a. Nenets

Тикавана тарем’ сырпа"ни, хамэдаб"нани сив' хункана я уэрха.

t'ikaßana tar'emf sir-pa?-n'i

along.that.place so look-VACOND-POSS.GEN.1.SG

hameda-b?-na-n'i s'iß-f hun-kana

notice-VACOND-NA-POSS.GEN.1.SG seven-GEN distance-LOC.SG 
ja ne- $\emptyset$-rha- $\emptyset$

land be-PRAES-APPROX-3.SG.S

'When I looked all over that place I noticed that there seemed to be the land at a distance of seven days.'

(Tereščenko 1990, 227)

b. Enets

Инэни но̄коно мигуа дяза. Куройхуо ага карє дязазарха.

ine-n’i nōkono m’igua

elder.brother-POss.1.SG to something

d'aza-a- $\emptyset \quad$ kurojhuo aga kar'e d'aza-za-rha- $\emptyset$

gO-IND.PRAES-3.SG.S some big fish go-PRAES-APPROX-3.SG.S

'Something is swimming to my elder brother. A big fish seems to be approaching.'

(Labanauskas 2002, 136)

Another special case worthy of note includes situations in which the subject observes the perceived entity in a dream by 'internal sight', that is, the subject experiences perceiving the entity in unreality.

(22) Nenets

Амгэ пиркана Лобэку сидя Вайхаюта ня ма: «Юдеми таня. Юдерпанани сеней уэдалёвани мюмня уоб уэдалёда тальня миђа, сеней хадавы, сяд падвы ерв минчарха. Сяд падвы ерв иленарха, торха. Нирхавы ха".»

amge p’irkana lobeku s’id’a ßaj-haju-ta n’a

after.a.while Lobaku two Vaj-DU-POss.3.sG friend

ma- $\emptyset-\emptyset \quad$ jud'e-m'i $\quad$ tan'a- $\emptyset-\emptyset$

say-IND.PRAES-3.SG.S dream-POSS.1.SG occur-IND.PRAES-3.SG.S

jud'er-pa-na-n'i s'en'ej

see.prophetic.dream-VACOND-NA-POSS.GEN.1.SG previous

nedal'o-ßa-n'i m’umn'a yob

ride.by.light.sledges-VNIPF-POSS.GEN.1.SG on one

yedal'oda tal'n'a m’ina- $\emptyset-\emptyset$ s'en'ej

rider then go-IND.PRAES-3.SG.S previous

hada- $\beta$ i s'ad pad $\beta \mathrm{i} \quad$ jer $\beta \quad$ m’in-ča-rha- $\emptyset \quad$ s'ad pad $\beta \mathrm{i} \quad$ jer $\beta$

kill-PP face tattooed master move-PRAES-APPROX-3.SG.S face tattooed master

il'e-na-rha- $\emptyset$ to- $\emptyset$-rha- $\emptyset$

live-PRAES-APPROX-3.SG.S come-PRAES-APPROX-3.SG.S

n'i- $\emptyset$-rha- $\beta \mathrm{i}-\emptyset$ ha-?

not-PRAES-APPROX-PERF-3.SG.S die-CONNEG

'After a while Lobaku has said to his two friends Vaj, "I have seen a dream. In my prophetic dream, one rider who was previously killed is going, he is following tracks of my previous riding by light sledges, the master with a tattooed face seemed to be moving. The master with a tattooed face seemed to be alive, seemed to be coming. It seemed that he did not die."'

(Labanauskas 2001, 89) 
The observer may contrast one and the same perceived entity, which was seen by 'internal sight' in a dream, with the entity observed in reality. In this case, the subject's doubts when identifying the entity could be explained not only by impediments during perception but also by imperfections of memory.

(23) Nenets

Парка Вай Лобэкон ма: «Юде̄на манэмэр чикы уэдакы?» «Dаa, чикар пэрханю".

Сияками юугу».

yarka $\beta$ aj lobekon ma- $\emptyset-\emptyset$

elder Vaj Lobakon say-IND.PRAES-3.SG.S

jud'ê-na mane-me-r č́iki ne-da-ki- $\emptyset$

dream-LOC.SG see-PP=2.SG.O this be-PRAES-INFER-3.SG.S

yaa čika-r ye- $\emptyset$-rha- $\emptyset=n^{\prime}$ u?

yes this-POSS.GEN.2.SG be-PRAES-APPROX-3.SG.S=PRTCL

s'ijaka-m’i jungu- $\emptyset-\emptyset$

lies-POSS.GEN.1.SG be.absent-IND.PRAES-3.SG.S

"The elder Vaj Lobakon says, "Apparently this is the person who you have seen in your dream?" "Yes, it seems that this is the one. I do not lie."'

(Labanauskas 2001, 87)

\subsubsection{The forms of the Approximative mood and their interaction with the category of tense in Nenets and Enets}

In Samoyedic linguistics, the study of the mood system is in an incomparably better position in Nenets than in Enets. In the period from the 1970s to the 1990s, a series of papers by K. Labanauskas were devoted to several Nenets moods, published in Linguistica Uralica. Also, Labanauskas provided the first detailed treatment of the Nenets 'наклонение кажущегося действия', termed in our work as the Approximative. In particular, he distinguished and described four different forms of this mood. Another serious attempt to coherently analyze the Nenets mood system was made by T. Salminen at the end of 1990s. The result has been the elaboration of a highly branched system of eighteen moods. Salminen notes that the four forms of 'наклонение кажущегося действия' recognized by Labanauskas equal his neologisms 'the approximative mood' and 'the hyperprobabilitive mood'. The first form corresponds to the imperfective approximative aorist, the second to the imperfective approximative preterite, the third to the heperprobabilitive, and the fourth to the futuritive approximative. Besides, Salminen distinguishes one more mood 'the perfective approximative' which, as he comments, is very rare and for this reason was not recorded by Labanauskas (1982, 283-292; Salminen 1997, 98-99). 
The only scanty data about the conjugation of the discussed verbal inflectional forms in Enets are available in a grammatical outline by Labanauskas where these forms appear under the term 'the second suppositional mood' (Labanauskas 2002, 56-57).

Since terminology regarding the Approximative forms is not unified across the Northern Samoyedic languages, and in order to avoid terminological confusion in our work, we will follow the distinction of four forms suggested by Labanauskas (1982).

The first form of the Approximative interacts with an aorist (Labanauskas 1982, 287), and refers to events that occurred without regard to their extension over time, or to states resulting from them (Aikhenvald 2004, 391).

In Nenets, the first form of the Approximative is formed by adding to the verb base one of the tense suffixes: $-\varnothing-,-n a-\left(-n^{\prime} a\right),-d a-\left(-d^{\prime} a-,-\delta a-\right.$, -ta-) followed by the markers of the Approximative -raha-/-laha-(-rha-, $\left.-r^{\prime} i h^{\prime} i-,-r h^{\prime} i-,-r h e-\right)$ and personal verbal endings of the required type of conjugation. It is worth mentioning that contrary to the most common view in Nenets grammar that 'zero morpheme' is one of the aorist markers, Salminen briefly observes that the cases with 'zero morpheme' plus the suffix $r \varnothing x a$ are better analyzed as deverbal derivations with the same suffix $(1997,99)$.

(24) Ирграв манту ихнянта манма: «Чеда̄в хэбнани саво уэрха.»

ingra $\beta$ mantu i-hn'an-ta

Ingrav Enets mind-LOC.SG-POSs.3.SG

$\operatorname{man}=\mathrm{ma}=\emptyset-\emptyset \quad \check{c}^{\prime} \mathrm{eda} \beta$

say $=$ PRTCL $=$ IND.PRAES-3.SG.S now

he-b-na-n'i saßo ye- $\emptyset$-rha- $\emptyset$

leave-VACOND-na-POSS.GEN.1.SG good be-PRAES-APPROX-3.SG.S

'An Enets, Ingrav has thought, "It seems to be good if I leave now".'

(Labanauskas 2001, 16)

In Enets, the first form of the Approximative is built by adding to the verb base the present tense affixes $-\not-_{-},-d a_{-}(-z a-)$ which are followed by the markers of the Approximative -rhaf-/-laha- and personal verbal endings of the required type of conjugation.

(25) Экихор онэй энчи идараха уа, оласнэ эзараха, парнэе.

ek'i-o-r onej enči

this-LIMIT-POss.2.SG genuine person 


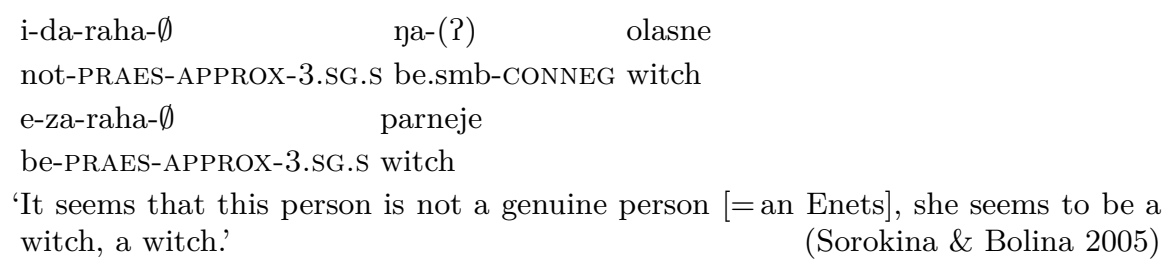

The second form of the Approximative denotes an irreal (seeming) action or state which precedes the moment of speaking. This form of the Approximative is rarely found in the available published works on Nenets and Enets.

In Nenets, the second form of the Approximative is generally constructed in the same manner as the first form of the Approximative. The only difference is that the personal endings of the verb are followed by the affix $-s^{\prime}$ or its phonetic variants. The second form of the Approximative is often accompanied by such adverbial modifiers as n'ér' 'earlier', śahaygaßa' 'some time ago', ta mal'ngana 'at that time', teńeb"nańi 'as far as I remember', etc., as well as various verbs used in the Past Indicative (Labanauskas 1982, 288).

(26) Ихнянта ма: «Хибя лаханаса юдерпанани? Тарем малхась: чуку яхад хэб" саво.»

i-hn'an-ta ma- $\emptyset-\emptyset \quad$ hi’b'a
mind-LOC.SG-POss.3.sG say-IND.PRAES-3.SG.S who
lahana-sa- $\emptyset$

converse-INTERR.PAST-3.SG.S see.prophetic.dream-VACOND-NA-POSS.GEN.2.SG

tar'em ma- $\emptyset$-lha- $\emptyset-s^{\prime} \quad$ č́uku ja-had

so say-PRAES-APPROX-3.SG.S-PAST this land-ABL.SG

he-b? saßo

leave-VACOND good

'He thought, "Who was speaking to me when I saw my prophetic dream? It seems that this someone told me that it was good if I left this land."'

(Labanauskas 2001, 67)

In Enets, the second form of the Approximative is formed similarly: the Approximative suffixes -rhaf-/-laha- are placed between the tense affix - $\varnothing$-, $-d a_{-}\left(-z a_{-}\right)$and the personal endings of the verb. The past tense affix $-s^{\prime}-$ occupies the final position in the morphological structure of the word.

(27) моди митодархабос̧ь

modi mita-da-rha-bo-s'

I give.back-PRAES-APPROX-1.SG.O-PAST

'It seemed that I did not give [something] back.'

(Labanauskas 2002, 57) 
The third form of the Approximative denotes an irreal (seeming) action or state which has been completed or was still happening before the moment of speech. The third form of the Approximative can be regarded as a specific type of perfect, namely, the perfect of result in which a present state is referred to as being the result of some past situation: this is one of the clearest manifestations of the present relevance of a past situation (Comrie 1976, 56). Unlike the second form of the Approximative that refers an action or state totally to the sphere of the past, the third form of the Approximative emphasizes the current relevance of an action or state to the moment of speaking. Contrast to the Perfect Indicative, the third form of the Approximative denotes a past action regarding which the subject has some doubts and therefore has to ambiguously describe this action.

In Nenets, the third form of the Approximative is formed from its first form by adding the perfect affix $-\beta^{\prime} i-/-\beta e-$, followed by the personal verbal endings of the required type of conjugation.

(28) Нями талирерхавы". Ет лаханаван ни харва". Тари уамчёва уамды, мунда юугу.

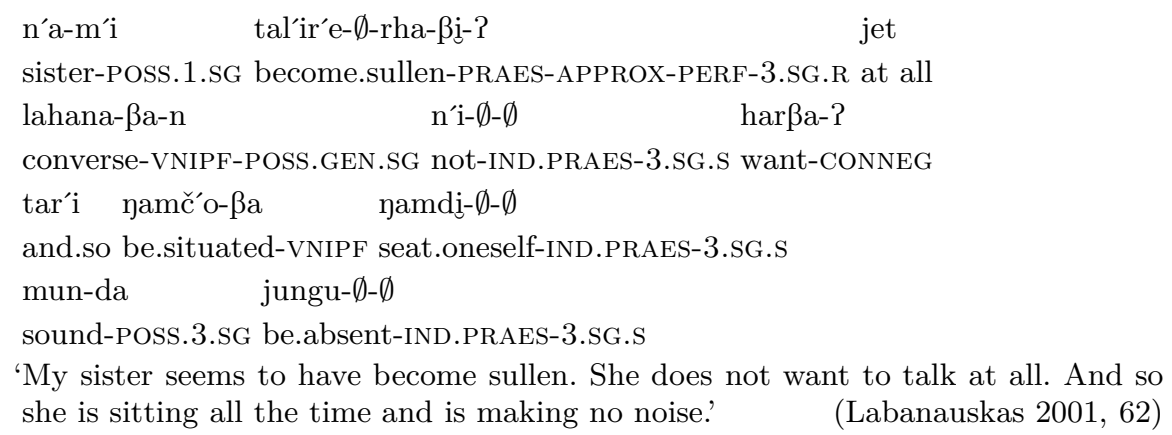

In Enets, the third form of the Approximative is built in a similar manner: the Approximative suffixes -rhaf-/-laha- are added to the present tense affix and then are followed by the perfect suffix -bi- and the personal verbal endings of the required type of conjugation.

(29) тонын кадрахаби

tonin ka-d-raha-b'i- $\emptyset$

there die-PRAES-APPROX-PERF-3.SG.S

'It seems that she has died there.'

(Labanauskas 2002, 80)

The fourth form of the Approximative is used to denote an irreal (seeming) action or state which will take place or will be going on after the moment of speaking (Labanauskas 1982, 290). This form expresses modal future and 
it covers not only a forthcoming but also any potential action or state. Due to this fact, the boundaries of the future tense become very 'fluid'.

In Nenets, the fourth form of the Approximative is built by adding to the verb base the future tense suffix $-\beta a n d a-\left(-\beta n d a_{-},-\beta n t a-,-\beta d a_{-}^{-}\right.$, -manda-, -mda-, - $\left.d a_{-}\right)$followed by the Approximative affixes -raha-/-laha$\left(-r h a_{-},-r h^{\prime} i\right.$-) and personal verbal endings of the verb.

(30) Вэсакохо', пухучаха' мауаха': «Хасава нюми амгэ тарча? Тадебя уэвандарха.»

Besako-hof puhuča-haf ma-nahaf

old.man-LOC.SG old.woman-LOC.SG say-IND.PRAES.3.DU.S

hasaßa n’u-m’i amge tarč́a tad'eb'a ye-ßanda-rha- $\emptyset$

man child-POss.1.SG what such shaman be-FUT-APPROX-3.SG.S

'The old man and old woman have said, "Why is our son like this? It seems that he will be a shaman.",

(Labanauskas 2001, 67)

In Enets, the fourth form of the Approximative is built by adding the future tense suffix $-\check{c}^{\prime} u z o$ - to the verb base followed by the Approximative affixes -rhaf(-)/-laha(-), and personal endings of the verb. This form of the Approximative is seldom found in the Enets texts.

(31) Абурий десума, ка̄чузорхазо.

abu-r'i-j d'esu-ma- $\emptyset \quad$ kā-č́uzo-rha-zo

head-LIMIT-POSS.1.SG ache-RES-3.SG.S die-FUT-APPROX-1.SG.S

'Only my head is aching, it seems I am going to die.' (Labanauskas 2002, 124)

\subsubsection{Transposed use of the Approximative}

As already mentioned, in the present paper, the semantics of the Approximative is analyzed from a paradigmatic and syntagmatic viewpoint. The crucial notion to describe the secondary (otherwise called transferred or syntagmatic) uses of the Approximative is that of 'transposition' - a term which is widely and differently employed in modern linguistics. As well known, in phonetics, transposition is associated with metathesis, i.e., the phenomenon when the sounds or syllables exchange positions with one another within a word due to assimilation or dissimilation. The formation of a word with the help of a metaphor or metaphorical use of a word is called semantic transposition. The process by which a word or a word base changes its part of speech into another part of speech or is used in the function of another part of speech is known as functional transposition.

We define transposition in grammar as a transferred (metaphorical) use of a word form or a syntactic structure in the function of its countermember in a paradigm set. In a morphological paradigm, transposition is 
always associated with the syntagmatic relations into which the word form enters with other units of the same level while the paradigmatic relations totally exclude it. Besides, transposition signals that when entering into syntagmatic relations, a word form may acquire new semantic properties. Also, it can be often associated with the neutralization of semantic oppositions, which is understood as a synonymic coincidence of the meanings of forms belonging to different paradigms within one morphological category. Despite the fact that transposition is the syntagmatic phenomenon located on the periphery of the grammatical system, it may occur that the number of neutralization cases exceeds the number of relevance cases. This results in a complete destruction of the previous opposition. On this ground, it is considered that transposition plays a crucial role in reorganizing morphological paradigms. (Kuznetsova 1995, 104; Kuznetsova 1995, 248).

\subsubsection{The 'Approximative into Inferential' transposition}

Examples of this type of transposition in Nenets and Enets are numerous. Both the Approximative and the Inferential express external objective modality within which they are opposed in the plane of irreality/reality. The modal semantics of reality expressed by the Inferential is strongly associated with the meaning of existence of a state of the present situation. It is important that the observed state is always the result of some previous event.

The moods are also opposed to each other by the feature direct (visual)-indirect (inferential) evidentiality. Two semantic types of the Inferential can be distinguished by the encoded source of information: Inferential-Inferentive and Inferential-Presumptive. The source of information for the former is phenomenological knowledge of the result of some event. The result in this case is connected with a judgment about the state of a definite situation based on the physical evidence. For the Inferential-Presumptive the source of information is the speaker's general knowledge foundation, i.e., the stored knowledge about the outside world. Since the speaker does not have exact information about the situation, the possibility of its different outcomes is not excluded.

The semantics shared by the Approximative and the Inferential is external subjective modality, in particular, indication of the observer's attitude to information, or its veracity. The semantic foundation for the transposed use of the Approximative in the sphere of functioning of the Inferential (Inferential-Inferentive and Inferential-Presumptive) rests on the meaning of problematic veracity (Kuznetsova \& Usenkova 2006, 279281). 
In the Approximative, insufficiency of information is explained by impediments in perception, whereas in the Inferential, it is associated with the absence of personal access to the situation: the perceiving subject makes judgments about the previous event via its results in the present state. In the case of the Approximative, general identification of the situation directly seen by the observer is made by indistinct visual characteristics. By contrast, the use of the Inferential indicates that the observer draws a conclusion regarding the cause of the situation by obvious evidence which can be easily observed although the situation itself was not seen (Aikhenvald 2004, 3).

Being used transpositionally in the sphere of functioning of the Inferential-Inferentive, the Approximative signals that the observer's inference about the existence of a situation in its present state is based on tangible evidence. When this occurs, the observer's inference bears greater confidence in the existence of a previous event. An Approximative used inferentially has more convincing force than an ordinary Approximative statement, which expresses the speaker's uncertainty regarding the perceived situation.

(32) a. Nenets

Нёнда тохоб" уод" ёмзянда уэвады. Џари" хахаяда яляхаваха"на пивна ядэрата яұгорахавы. Тикы' тарця уэсь нём' сируав. Тараси" уэбта теркоховада танянарханё" - сюнада моргэнё".

n'o-nda toho-b?

entrance.hole.of.the.tent-POSS.GEN.3.SG be.snowed.in-VACOND

jod? jomz'a-nda

also soft.fluffy.snow-POSS.GEN.3.SG

yeßadi- $\emptyset-\emptyset$ yar'i? hahajada

be.at.rest-IND.PRAES-3.SG.S right now nearest

jal'a $=$ haßa=ha?na p'i- $\beta$ na jadera-ta

day $=$ PRTCL $=$ LOC.SG night-PROL.SG wander-PRP

ango- $\emptyset$-raha- $\beta \mathrm{i}-\emptyset$ t'ikif

be.absent-PRAES-APPROX-PERF-3.SG.S that

tarc'a ye-s' n’o-mf

such be-VAINF entrance.hole.of.the.tent-ACC.SG

s'irna- $\emptyset-\beta \quad$ taras'i?

dig.out-IND.PRAES-3.SG.o but

ye-bta- $\emptyset-\emptyset \quad$ t'er-ko=hoßa $=$ da

be.situated-RES-IND.PRAES-3.SG.S dweller-DIM $=$ PRTCL=POSS.3.SG

tan'a-na-rha- $\emptyset=$ n'o? s'una-da

exist-PRAES-APPROX-3.SG.S=PRTCL smoke-POSS.3.SG 
mo-nge- $\emptyset-\emptyset=$ n'o?

curl-NP-IND.PRAES-3.SG.S $=$ PRTCL

'Though the entrance hole of the tent is buried under snow, the layer of the soft fluffy snow has not been touched. Recently nobody seems to have wandered about. Let it be so, I have dug out the entrance hole of the tent. However, a dweller is evidently there because smoke is curling upwards.'

(Tereščenko 1990, 179)

b. Enets

Тоз чикоз тоныз пазуй сєз пере озима. «Оу, чикир сєз пазуй оша эзараха.»

to $\delta$ čikoz toniz pazuj s'es p'er'e

later from there tattooed face half

oz'i-ma- $\emptyset-\emptyset$ ou čik'ir s'e3

appear-RES-IND.PRAES-3.SG.S oh this-POSS.2.SG face

pazuj oša e-za-raha- $\emptyset$

tattooed Tungus be-PRAES-APPROX-3.SG.S

'Later half of a tattooed face appeared from there. "Oh, this face is evidently a tattooed Tungus."

(Sorokina \& Bolina 2005)

When the Approximative is transposed into the sphere of functioning of the Inferential-Presumptive, the state of the present situation is viewed as conjecture or assumption. The speaker expresses the supposition that the assumed outcome of this situation may coincide with reality though other outcomes may also happen.

(33) a. Nenets

Тиканда Тэта хабт луца, пыда тарем' ма: «Вэнуга ұацекым’ Печоров яв' саляни ервуэ вадарахавэв.»

t'ikanda teta habt luca

then a.rich.reindeer.herder castrated Russian

pida tar'emf ma- $\emptyset$ -

he so say-IND.PRAES-3.SG.S

ßenyga yac'eki-mf p'eč́oro $\beta$ jaß-

Vanga child-ACC.SG Pechora sea-GEN.SG

sal'a-n'i jer $\beta=$ ne $\quad \beta a d a-\emptyset$-raha- $\beta$ - $\beta$

cape-POSS.GEN.1.SG landlord=TRANSL raise-PRAES-APPROX-PERF-1.SG.S

'A rich reindeer herder, a castrated Russian, he has said, "It seems that I have raised the child Vanga as the landlord of the cape of the Pechora Sea."'

(Tereščenko 1990, 257)

b. Enets

Дерэ дябахон кудазархаба".

d'ere d'aba-hon kuda-za-rha-ba?

day length-LOC.SG sleep-PRAES-APPROX-1.PL.S

'It seems that we have slept for the whole day.'

(Labanauskas 2002, 132)

Acta Linguistica Hungarica 61, 2014 


\subsubsection{The 'Approximative into Auditive' transposition}

The transposed use of the Approximative in the sphere of functioning of the Auditive is quite common in Nenets and Enets. The semantic basis of the 'Approximative into Auditive' transposition is direct perceptual information about a situation to which the observer has direct access. The examples we have at our disposal show that the Approximative can replace the Auditive in the meaning of 'acquiring information through hearing' only when it marks the predicates of active semantics expressed by the verbs of sounding and speaking. Verbs of this group have a common semantic component - 'a sound' - and are naturally associated with perception by hearing.

(34) Nenets; the verbs: lahanas' 'speak', 'talk'; sambădorc' 'speak with the soul of a deceased person'

Хонёбата уод" еваку рачекы пи ямпхана тургус сёвна пили" самбадоруа, самбадортараха.

hon'o-ba-ta nod? jeßa-ku načeki

sleep-DUR-PRP also orphan-DIM child

p'i jamphana tungus s'o- $\beta$ na p'il'i?

night during Tungus throat-PROL constantly

sambadorya- $\emptyset-\emptyset$

speak.with.soul.of.deceased.person-IND.PRAES-3.SG.S

sambador-ta-raha- $\emptyset$

speak.with.soul.of.deceased.person-PRAES-APPROX-3.sG.S

'During the night, also [when] sleeping, the orphan is constantly speaking in the Tugus language with the soul of a deceased person, he is heard as if speaking with the soul of a deceased person.'

(Labanauskas 2001, 67)

(35) Enets; the verbs: d'or'id' 'speak', 'talk'; leud' 'shout', 'make noise'; p'is'id' 'laugh' Онсехода, сеха дёридарха.

ons'ehoda s'eha d'or'i-da-rha- $\emptyset$

indeed somebody talk-PRAES-APPROX-3.SG.S

'Indeed, somebody is heard as if talking.'

(Sorokina \& Bolina 2005)

When the Approximative is used transpositionally, it focuses on the subjective impression of the perceiving subject and is affected by auditory impediments during perception. At the same time, the forms of the Approximative indicate that the observer has direct access to the situation and personal access to the information source. 
(36) a. Nenets

Юдерпананта уоб лаханана лахнанараха: «Еваку уачекы, чуку, яв вархана пон нён мы».

jud'er-pa-na-nta nob lahana-na

see.prophetic.dreams-VACOND-NA-POSS.3.SG one speaker-PRP lahna-na-raha- $\emptyset \quad$ jeßa-ku načeki č'uku

speak-PRAES-APPROX-3.SG.S orphan-DIM child that

jaß $\beta$ ar-hana pon mi-?

sea shore-LOC.SG for.long.time not-IND.PRAES-2.SG.S stay-CONNEG

'When he has been seeing prophetic dreams some spearker is heard as if speaking, "Orphan-child, do not stay for a long time on that sea shore!"”

(Labanauskas 2001, 67)

b. Enets

Обу дёдигон нэ эчи ноддархаза, кабе касаза нода дёридарха, мадараха нода:

«Аба, эу съий из пуу...»

obu d'od'igon ne eči

what during woman young

nod-da-rha-za kab'e kasa-za

hear-PRAES-APPROX-3.SG.R dead sister-POSS.3.SG

noda d'or'i-da-rha- $\emptyset$

she[-DAT] speak-PRAES-APPROX-3.SG.S

ma-da-raha- $\emptyset$ noda aba eu

say-PRAES-APPROX-3.SG.S she[-DAT] elder.sister here

$\mathrm{s}^{\prime} \mathrm{ij} \quad$ iz puu- $\emptyset-(?)$

I $[-\mathrm{ACC}]$ not put-IMP-2.SG.S

"All of a sudden it seems to the girl that she hears, the dead sister as if heard speaking to her, as if heard saying to her, "Elder sister, do not put me here." (Sorokina \& Bolina 2005)

When the Approximative is transposed into the sphere of functioning of the Auditive, the former always indicates an explicit and concrete source of information.

(37) a. Nenets

Пыда мандараха: «Недко Нохой, тюня’ уа"...»

pida man-da-raha- $\emptyset$ n'e-dko

he say-PRAES-APPROX-3.SG.S woman-from.the.clan

nohoj t'un'af na- $\emptyset-?$

Nohoj up be-IMP-2.SG.S

'He is heard as if saying, "The woman from the clan of Nohoj, stand up!"'

(Tereščenko 1990, 196) 
b. Enets

Парнэ мадараха: «Онэй нэ, онэй нээ, торь с̧ит мус̧ь комазудь.»

parne ma-da-raha- $\emptyset \quad$ onej ne

witch say-PRAES-APPROX-3.SG.S genuine woman

onej nee tor' s'it

genuine woman in.this.way you[-ACC]

mus' koma-zu-d'

capture-VAINF want-1.SG.S-IND.PAST

'The witch is heard as if saying, "An Enets woman, an Enets woman, in this way I wanted to capture you."”

(Sorokina \& Bolina 2005)

\subsubsection{The 'Approximative into Subjective-Debitive' transposition}

This type of transposition is very seldom found in the published Nenets and Enets texts. In fact only the fourth form of the Approximative can be transposed into the sphere of the Subjective-Debitive. Being realized in the Future tense, the Approximative expresses the semantics of projectivity (futurity) and presents an action as supposed in the future, but at the same time connected with the present. Thus, it demonstrates a specific 'relevance of anteriority of the fact' (Tsejtlin 1990, 149). The categorial meaning of the Subjective-Debitive is internal modality of necessity complicated by the meaning of supposition (Usenkova 2007, 188). The shared semantics for both moods is potentiality. By transposing into the sphere of functioning of the Subjective-Debitive, the Approximative characterizes the situation as impossible to avert or avoid, irrespective of the desired goal. But along with this, due to the semantics of subjectivity, the meaning of inevitability expressed by the Approximative is weakened and the situation is evaluated as prospective, predicted with a high degree of probability in the future.

(38) a. Nenets: тедахава' пармбэй хасава' хэвхана пуромӑндарӑхадм

t'eda=haßaf narmbej hasaßa- $f \quad$ he- $\beta$ hana

now $=$ PRTCL old husband-GEN.SG side-DAT.SG

puro-mănda-raha-dm

get.moldy-FUT-APPROX-1.SG.S

'and now I will have to get moldy by my old husband' (Tereščenko 1965, 490)

b. Enets: Пагиза дягу тухон порзас̧ь сойза эзараха.

pag'i-za d'agu- $\emptyset-\emptyset$ tu-hon

clothes-POss.3.SG be.absent-IND.PRAES-3.SG.S fire-LOC.SG

porza-s' sojza e-za-raha- $\emptyset$

set.on.fire-VAINF well be-PRAES-APPROX-3.SG.S

'She has no clothes on, her body must be probably set on fire.'

(Sorokina \& Bolina 2005) 


\subsubsection{The 'Approximative into Conjunctive' transposition}

This type of transposition is rare and is recorded only in Nenets. Being transposed into the sphere of functioning of the Conjunctive, the fourth form of the Approximative expresses internal modality of possibility. Like the Conjunctive the fourth form of the Approximative also enters the sphere of potentiality. Moreover, the semantics of both moods is based on the meaning of conditionality which presupposes that fulfillment of an action or state is contingent on some conditions, causes, or circumstances. In the Conjunctive conditionality is associated with objective circumstances, whereas in the Approximative it is related with cognizance of the speaker. When forms of the Approximative replace the Conjunctive they describe an action as potential, possible, or contingent on definite objective circumstances.

(39) Nenets

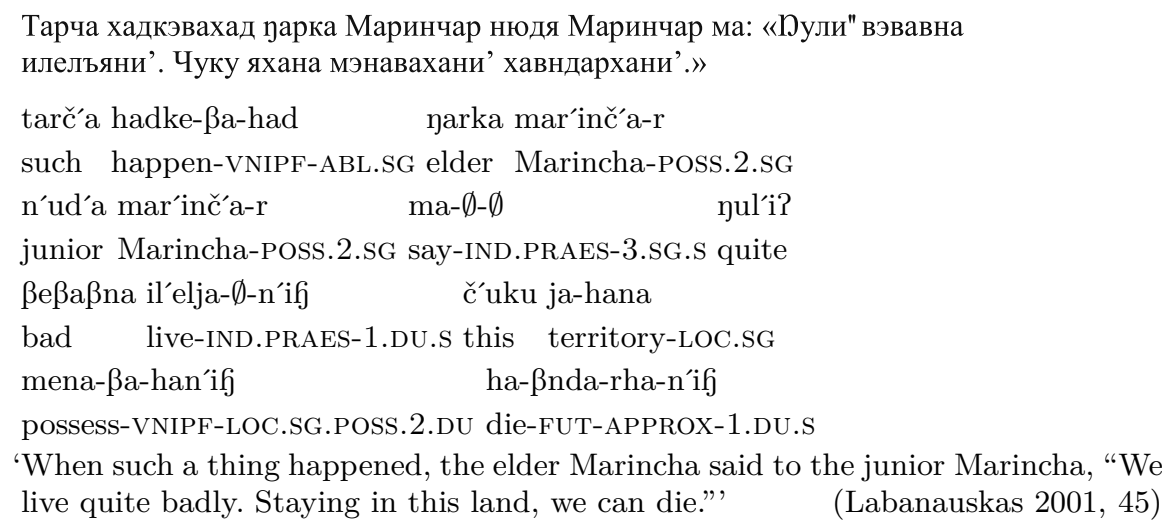

\subsubsection{The 'Approximative into Interrogative into Indicative' transposition}

The Approximative unites with the Interrogative by the feature 'reporting of information', which in this case may be qualified as 'diffident reporting'. Therefore, both moods express external subjective modality. The Approximative can further be transposed into the sphere of functioning of the Indicative, neutral and most capacious in its semantics, and be realized in rhetorical sentences (Usenkova 2002, 55). It should be noted that a rhetorical question in principle cannot be considered a genuine question as it is not intended for getting a verbal reaction from the hearer. In fact, by uttering a rhetorical question the speaker emphatically accentuates its intensely declarative semantic nature. The use of the Approximative in such sentences testifies that the speaker has found the situation unexpected and that it arouses surprise. Exclamation which normally accompanies the 
rhetorical question serves to express either disbelief ('It cannot be true!', 'I do not believe my eyes!') or disapproval ('Oh, no! How can it be so!') regarding the situation witnessed by the speaker. The admirative semantics indicates that only recent evidence enables the speaker to arrive at the conclusion and that earlier the reverse was assumed.

(40) Nenets

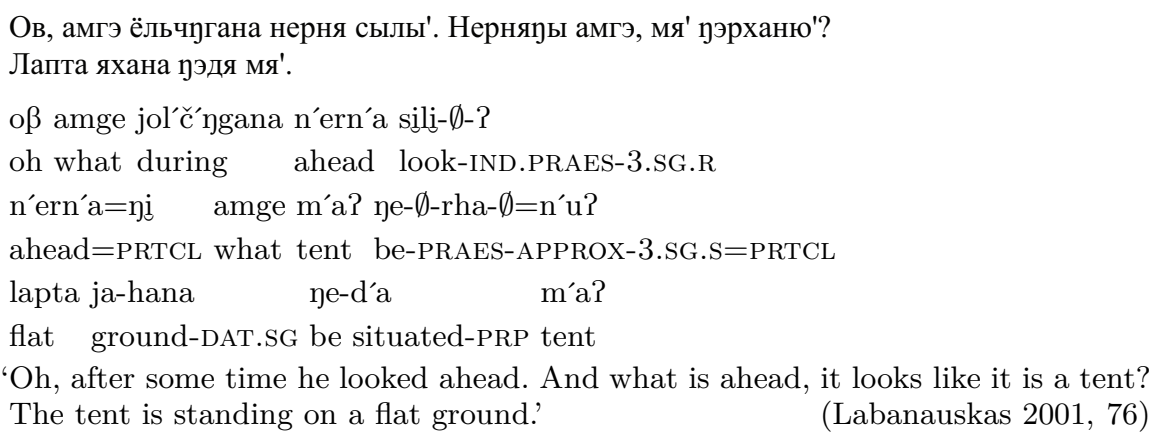

\section{Conclusion}

In this paper, we have dwelled upon the functions of the Nenets suffixes -raha-/-laha-, Enets rhaf-/-laha-, and Nganasan -raku-/-ragu-/-laku-/-la$g u-$. The three functions which were determined are: word formative (derivational), form-building, and inflectional. In Nenets, these suffixes are found to be used in all the three functions; in Enets, they can perform the form-building and inflexional functions; in Nganasan, the suffixes are employed only in the form-building function. Thus, the only common function which the analyzed suffixes in all the Northern Samoyedic languages can perform is form-building.

When the suffixes are used in the form-building function they are termed 'simulative'. In the comparative constructons, they mark the noun and act as an index of comparison. Specificity of these constructions consists in that the standard and parameter of comparison are expressed synthetically. Semantically, the suffixes signal that two discrete entities are figuratively compared in the qualitative aspect. This type of comparison by similarity is termed 'object comparison'.

By likening two entities, the speaker has to choose the parameter of comparison, i.e., the feature inherent in both the comparee and the standard of comparison. By the character of the chosen quality, the following types of differential features are distinguished: 
1. Qualitatively-defining features which denote various physical qualities of the object such as shape, size, color, substance, stability.

2. Functional features which point out the intended use of the objects.

3. Quantitative features which indicate the quantity of the objects.

The object comparison is opposed to the situational comparison where the analyzed suffixes mark the verb. Performing the inflexional function they participate in forming the Approximative mood and, thus, are a morphological means of expressing modality.

The paradigm of the Approximative in Nenets and Enets is built on the opposition of three persons $(1,2,3)$, three numbers (singular, dual, plural), three types of conjugation (subjective, objective, reflexive), and includes the personal verbal endings common for most of the moods. The place of the Approximative suffix in a word depends on the position and structure of the tense affixes.

The paradigmatic (categorial) meaning of the Approximative is the external objective modality of irreality complicated by the meaning of subjective visual perception. In this meaning the Approximative is used in declarative sentences of irreal comparison. Declarative sentences present information as a fact or affirmation. It is important that in this case affirmation is realized only in such a narrative speech form as description. The examples we have at our disposal show that only the Nenets Approximative has retained a full paradigmatic meaning.

Sentences of irreal comparison demonstrate rather relations of causality than similarity. The paradigmatic meaning of the Approximative is complicated by the meaning of subjective visual perception. According to our observations, the use of the Approximative forms clearly demonstrates that the meaning of subjective visual perception is actively suppressing the semantics of external objective modality of irreality in Nenets and has already become dominant in Enets since the Approximative seems to be no longer realized in declarative descriptive sentences.

The meaning of subjective visual perception is a special case of a more general semantics of seemingness, defined as subjective impression or subjective perception. It combines the semantics of evidentiality and that of external subjective modality. The evidential aspect of seemingness implies that information is acquired visually and the observer is in direct contact with the situation under evaluation. By contrast, the semantic components of irreal comparison - irreality, implied conditionality, and comparativity - expressed by the Approximative, substantially contribute to the development of the subjective semantics related to the speaker's attitude 
to information, or its veracity. Due to the fact that the information is acquired directly and through vision, the Approximative describes events the probability of whose realization is high. At the same time, these situations could be characterized by problematic veracity inasmuch as impediments during perception prevent the observer from obtaining sufficient information. The meaning of uncertainty expressed by the Approximative forms favours the formation of 'uncertain reports'. For this reason, subjective visual perception could be termed 'uncertain visual'.

In Nenets and Enets, the Approximative can be found in one of its four forms, each of which interacts with the semantics of a corresponding tense: the present, past, perfect, and future. The first form of the Approximative is used with an aorist and refers to events that occurred without regard to their extension over time, or states resulting from them. The second form of the Approximative denotes an irreal seeming action or state which precedes the moment of speaking. The third form of the Approximative manifests the present relevance of a past situation. It also denotes a past action regarding which the subject has some doubts and, therefore, has to ambiguously describe this action. The fourth form of the Approximative is modal in nature and is used to refer to not only a forthcoming but any potential action or state.

Since the semantic scope of the first and third forms of the Approximative appears to be quite large, these forms are most frequently found in Nenets and Enets texts. By contrast, the forms of the second and fourth forms of the Approximative are characterized by highly specialized semantics; examples of their use are few in number.

Both in Nenets and Enets, the Approximative enjoys numerous transpositional possibilities. We distinguished the following types of transpositions with the participation of the Approxiamative:

(i) The 'Approximative to Inferential' transposition.

In Nenets and Enets, the Approximative and the Inferential stand in a strong opposition. In their paradigmatic meaning the Approximative and the Inferential express external objective modality within which they are opposed in the plane of irreality/reality. They are also opposed to each other by the feature visual/inferential evidentiality. The shared semantics is external subjective modality, in particular, indication of the observer's attitude to information. The semantic foundation for the transposed use of the Approximative in the sphere of functioning of the Inferential (Inferential-Inferentive and Inferential-Presumptive) rests on the epistemic meaning of problematic veracity. 
Replacing the Inferential-Inferentive, the Approximative signals that the observer's inference about the existence of a situation is based on tangible evidence, and it has more convincing force than an ordinary Approximative statement associated with the speaker's uncertainty about the veracity of the situation.

When the Approximative is transposed into the sphere of functioning of the Inferential-Presumptive, the state of the present situation is viewed as conjecture or assumption. The speaker expresses the supposition that the assumed outcome of this situation may coincide with reality although other outcomes may also happen.

(ii) The 'Approximative into Auditive' transposition.

In Nenets and Enets, the Approximative-Auditive opposition is regarded to be strong as the moods are opposed to each other in their paradigmatic meanings by the feature of visual/non-visual evidentiality. Both moods express external objective modality, where they are opposed in the plane of reality/irreality. The basis for this transposition is a shared meaning of direct perception that underlies the semantics of both moods. The Auditive realizes the meaning of non-visual perception in the sensory sphere that exists for the observer as a situation of the highest degree of reality, which is actuality. The Approximative realizes the meaning of perception in the sphere of irreal comparison as subjective visual perception (seemingness). The semantics of this mood signals that the information acquired by the observer is distorted because of some impediments in perception. By transposing into the sphere of functioning of the Auditive, the Approximative specifies a different source of information and attendant circumstances of obtaining information: the perceiving subject acquires first-hand information that turns out to be distorted through impediments in hearing.

(iii) The 'Approximative into Subjective-Debitive' transposition.

This type of transposition is very uncommon. The transposition occurs only when the Approximative is used in the future tense. The Subjective-Debitive expresses internal modality of necessity complicated by the meaning of supposition. Thus, the strong Approximative-Subjective-Debitive opposition is based on the meaning of potentiality, which integrates heterogeneous modal meanings (necessity, reality, irreality, unreality, reliability, intentionality, and many more), and which is always present to a certain degree in the semantics of utterances referring to the future. Within the limits of another shared semantic sphere, external subjective modality, both moods may express the highest degree of probability. Therefore, when the Approximative functions in the semantic sphere of the Subjective-Deb- 
itive, it characterizes a situation as inevitable and going to happen in the future with a high degree of probability.

(iv) The 'Approximative into Konjunctive' transposition.

This type of transposition is rare and is recorded only in Nenets. The Konjunctive is replaced only by the Future Approximative. In the plane of modality, the strong Approximative/Konjunctive opposition is not homogeneous as the moods belong to different types of modality: external objective modality and internal modality of possibility correspondingly. The semantic basis for this opposition is the shared semantics of potentiality. Replacing the Konjunctive, the Approximative describes an action as potential, possible, or contingent on definite objective circumstances.

(v) The 'Approximative into Interrogative into Indicative' transposition.

This transposition is rare and is recorded only in Nentes. The Approximative and the Interrogative are strongly opposed to each other in the plane of communicative modality, where they are realized in sentences of different communicative types - declarative and interrogative correspondingly. The semantic basis for this transposition is external subjective modality, in particular, the meaning of 'reporting of information', which in case of both moods is qualified as 'diffident reporting'. Further transposition of the Approximative in the interrogative meaning into the sphere of functioning of the Indicative contributes to the emergence of a specific stylistic effect. This opposition is also strong as regarding modality the Indicative is neutral and therefore is of the most capacious semantics.

The present study of the Approximative in Nenets and Enets has demonstrated how the changes taking place in the paradigmatic meaning of the moods influence their functional possibilities. Within the limits of the paradigmatic meaning, the contaminated modal-evidential meaning of seemingness appears to be more powerful and capacious than the originally principal modal meanings of irreality and implied conditionality. As a result, in Nenets, the meaning of seemingness actively suppresses these original meanings, whereas in Enets, it has already fully superseded them. In both languages these changes enable the Approximative to extensively transpose into the functional sphere of two other evidential moods - the Inferential and the Auditive. By contrast, their functioning in the sphere of the non-evidential Subjective-Debitive and the Konjunctive moods is severely restricted by pure modal semantics which requires that only the future forms of the Approximative be used transpositionally. The transposition of the Approximative into the functional sphere of the Interrogative and then the neutral Indicative is used to create a certain stylistic effect. 


\section{References}

Abaev, Vasilij I. 1964. A grammatical sketch of Ossetic. The Hague: Mouton.

Abondolo, Daniel (ed.). 1998. The Uralic languages. London \& New York: Routledge. Aikhenvald, Alexandra Y. 2004. Evidentiality. Oxford: Oxford University Press.

Aikhenvald, Alexandra Y. 2006. Evidentiality in grammar. In K. Brown (ed.) Encyclopedia of language and linguistics. Vol. 4. Oxford: Elsevier. 320-325.

Akmajian, Adrian, Richard A. Demers, Ann K. Farmer and Robert M. Harnish. 2010. Linguistics: An introduction to language and communication. Cambridge MA: MIT Press.

Alhoniemi, Alho. 1993. Grammatik des Tscheremissischen (Mari). Mit Texten und Glossar. Hamburg: Helmut Buske.

Andersen, Paul K. 1983. Word order typology and comparative constructions. Amsterdam \& Philadelphia: John Benjamins.

Aronoff, Mark and Kirsten Fudeman. 2011. What is morphology? (Second edition). Malden MA \& Oxford: Blackwell.

Arutjunova, Nina D. (ed.). 1993. Logičeskij analiz jazyka. Mentaljnyje dejstvija. Moskva: Nauka.

Auwera, Johan van der (ed.). 1998. Adverbial constructions in the languages of Europe. Berlin \& New York: Mouton de Gruyter.

Auwera, Johan van der and Vladimir A. Plungian. 1998. Modality's semantic map. Linguistic Typology 2. 79-124.

Barker, Chris and Christopher Kennedy. 2009. General preface. In Paul Portner, Modaity. Oxford: Oxford University Press. xi.

Bauer, Laurie. 2004. A glossary of morphology. Washington, D.C.: Georgetown University Press.

Beljaeva, Elena I. 1990. Dostovernostj. In Bondarko (1990b, 157-170).

Bisang, Walter. 1998. Adverbiality: The view from the Far East. In Auwera (1998, 641812).

Boldt, Ekaterina P. 1989. Imennoje slovoobrazovanije nganasanskogo jazyka. Novosibirsk: Nauka.

Boller, Anton. 1857. Die Übereinstimmung der Tempus- und Moduscharaktere in den ural-altaischen Sprachen. In Sitzungsberichte der Philosophisch-Historischen Classe der Kaiserlichen Akademie der Wissenschaften. XXII. Band. II. Heft. Jahrgang 1856, December. Wien: Akademie der Wissenschaften. 223-263.

Bondarko, Alexandr V. 1990a. Realjnostj/irrealjnostj i potentsialjnostj. In Bondarko (1990b, 72-79).

Bondarko, Alexandr V. (ed.). 1990b. Teorija funktsionaljnoj grammatiki. Temporaljnostj. Modaljnostj. Leningrad: Nauka.

Booij, Geert. 2010. Construction morphology. Oxford: Oxford University Press.

Brown, Keith and Jim Miller (eds.). 1999. Concise encyclopedia of grammatical categories. Oxford: Elsevier.

Bublitz, Wolfram. 1978. Ausdrucksweisen der Sprechereinstellung im Deutschen and Englischen. Untersuchungen zur Syntax und Pragmatik der deutschen Modalpartikeln und Vergewisserungsfragen und ihrer englischen Entsprechungen. Tübingen: Niemeyer. 
Bulygina, Tamara V. and Alexej D. Šmeljov. 1993. Gipoteza kak mysliteljnyj i rečevoj akt. In Arutjunova (1993, 78-82).

Burkova, Svetlana I. 2004. Evidentsialjnostj i epistemičeskaja modaljnostj v nenetskom jazyke. In Y. A. Lander, V. A. Plungjan and A. Y. Urmančiev (eds.) Issledovaniya po teorii grammatiki 3. Irrealis i irrealjnostj. Moskva: Gnozis. 353-374.

Bužarovska, Eleni. 2005. Equality versus similarity constructions in English. Journal of Language and Linguistics 4. 74-99.

Bybee, Joan L. and Susan Fleischman. 1995. Modality in grammar and discourse: An introductory essay. In J. Bybee and S. Fleischman (eds.) Modality in grammar and discourse. Amsterdam: Benjamins. 1-14.

Castrén, Matthias Alexander. 1854/1969. Grammatik der samojedischen Sprachen. Hrsg. von Anton Schiefner $=$ Nordische Reisen und Forschungen 7. St. Petersburg \& Leipzig: Buchdruckerei der Keiserlichen Akademie der Wissenschaften.

Comrie, Bernard. 1976. Aspect. An introduction to the study of verbal aspect and related problems. Cambridge: Cambridge University Press.

Crookston, Ian. 1994. Comparative constructions. In R. Asher and J. M. Y. Simpson (eds.) The encyclopedia of language and linguistics 2. Oxford: Pergamon Press. 624-629.

Čeremisina, Maja I. 1973. Složnyje sravniteljnyje konstruktsii russkogo jazyka. Abstract of Habilitation Thesis. Novosibirsk.

Čeremisina, Maja I. and Ljudmila A. Shamina. 1996. Vyraženije sravnenija v tuvinskom jazyke. Jazyki korennyh narodov Sibiri 3. 65-84.

Daniel, Mikhail A. and Valentin Y. Gusev. 2003. Nagÿr ninyde [Three brothers]. Korpus nganasanskih foljklornyh tekstov. http://www.iling-ran.ru/gusev/Nganasan/texts/index.php (accessed 17 July 2011).

Davidsen-Nielsen, Niels. 1990. Tense and mood in English. A comparison with Danish. Berlin \& New York: Mouton de Gruyter.

Devitt, Michael and Kim Sterelny. 1999. Language and reality: An introduction to the philosophy of language. Cambridge MA: MIT Press.

Dixon, Robert M. W. 2010. Basic linguistic theory. Volume 1: Methodology. Oxford: Oxford University Press.

Dixon, Robert M. W. 2012. Basic linguistic theory. Volume 3: Further grammatical topics. Oxford: Oxford University Press.

Ermolaeva, Ljudmila S. 1987. Očerki po sopostaviteljnoj grammatike germanskih jazykov. Moskva: Vysšaya škola.

Gagkajev, K. E. 1956. Sintaksis osetinskogo jazyka. Ordžonikidze: Severo-Osetinskoje knižnoje izdateljstvo.

Gisborne, Nikolas and Jasper Holmes. 2007. A history of English evidential verbs of appearance. English Language and Linguistics 11. 1-29.

Givón, Talmy. 2001. Syntax: An introduction (Volume I \& II). Amsterdam \& Philadelphia: John Benjamins.

Goodman, Nelson. 1971. Seven strictures on similarity. In L. Foster and J. W. Swanson (eds.) Experience and theory. London: Duckworth. 19-31.

Gusev, Valentin Y. 2007. Evidentsialjnostj v nganasanskom jazyke. In Hrakovskij (2007, 415-444). 
De Haan, Ferdinand. 2008. Semantic distinctions of evidentiality. In M. Haspelmath, M. S. Dryer, D. Gil and B. Comrie (eds.) The world atlas of language structures online. Munich: Max Planck Digital Library. Chapter 77. http://wals.info/feature/description/77 (accessed 17 July2011).

Halliday, Michael Alexander Kirkwood. 1985. An introduction to functional grammar. London: Edward Arnold.

Haspelmath, Martin and Olga Buchholz. 1998. Equative and simulative constructions in the languages of Europe. In Auwera (1998, 277-334).

Helimski, Eugene A. 1994. Očerk morfonologii i slovoizmeniteljnoj morfologii nganasanskogo jazyka. In E. A. Helimski (ed.) Tajmyrskij etnolingvističeskij sbornik: Materialy po nganasanskomu šamanstvu i jazyku 1. Moskva: RGGU. 190-221.

Helimski, Eugene A. 1998. Nganasan. In Abondolo (1998, 480-515).

Helimski, Eugene A. 2001. Samoyedic studies: A state-of-the-art report. Finnisch-Ugrische Forschungen 56. 175-216.

Hrakovskij, Viktor S. (ed.). 2007. Evidentsialjnostj v jazykah Evropy i Azii. St. Petersburg: Nauka.

Ioanesân, Evgenija R. 1993. Klassifikatsiya mentaljnyh predikatov po tipu vvodimyh imi suždenij. In Arutjunova (1993, 89-95).

Jacobson, Steven A. 1995. A practical grammar of the Central Yup'ik Eskimo language. Fairbanks: Alaska Native Center.

Janhunen, Juha. 1998. Samoyedic. In Abondolo (1998, 457-479).

Kiefer, Ferenc. 1999. Modality. In Brown \& Miller (1999, 223-229).

Kostjorkina, Nadežna T., Alexander Č. Momde and Tatjana Y. Ždanova. 2001. Slovarj nganasansko-russkij i russko-nganasanskij. St. Petersburg: Prosveščenije.

Kratzer, Angelika. 1981. The notional category of modality. In H.-J. Eikmeyer and H. Rieser (eds.) Words, worlds, and contexts: New approaches to word semantics. Berlin: Walter de Gruyter. 38-74.

Kuprijanova, Zinaida N., Marija Y. Barmič and Ljudmila V. Homič. 1985. Nenetskij jazyk. Učebnoje posobije dlja pedučilišč. Leningrad: Prosveščenije.

Kuznetsova, Nadežda G. 1995. Grammatičeskije kategorii južno-seljkupskogo glagola. Tomsk: TGPU.

Kuznetsova, Nadežda G. and Eleonora V. Usenkova. 2003. Sredstva vyraženija modaljnyh značenij v nganasanskom jazyke. Linguistica Uralica 40. 266-275.

Kuznetsova, Nadežda G. and Eleonora V. Usenkova. 2006. Inferentsial v nenetskom jazyke. Linguistica Uralica 42. 276-296.

Künnap, Ago. 1978. System und Ursprung der Kamassischen Flexionssuffixe. II. Verbalflexion und Verbalnomina. Helsinki: Suomalais-Ugrilainen Seura.

Labanauskas, Kazimir. 1982. Naklonenije kažuščegosja dejstviya. Sovetskoje Finno-Ugrovedenije 4. 283-292.

Labanauskas, Kazimir. 2001. Skazy sedoj stariny. Nenetskaja foljklornaja hrestomatija. Moskva: Russkaja literatura.

Labanauskas, Kazimir. 2002. Rodnoje slovo. St. Petersburg: Prosveščenije.

Lamber, Jean-Luc. 1997. Djajku. Korpus nganasanskih foljklornyh tekstov. http://www.iling-ran.ru/gusev/Nganasan/texts/index.php (accessed 17 July 2011). 
Lewis, David. 1985. On the plurality of words. Oxford \& Cambridge MA: Blackwell.

Ljublinskaja, Marina D. and Maljčukov Andrej L. 2007. Evidentsialjnostj v nenetskom jazyke. In Hrakovskij (2007, 445-46).

Mel'čuk, Igor. 1998. Kurs obščej morfologii. Tom II. Čast' vtoraja: morfologičeskie značenija. Moskva: Jazyki russkoj kul'tury.

Menges, Karl H. 1968. The Turkic languages and peoples: An introduction to Turkic studies. Wiesbaden: Otto Harrassowitz.

Mezenin, Sergej M. 1969. Konstruktsii sovremennogo anglijskogo jazyka, imejuščije značenije sravnenija. Doctoral dissertation. Moskva.

Mikola, Tibor. 1995. Morphologisches Wörterbuch des Enzischen (Studia Uralo-Altaica 36). Szeged: Universitas Szegediensis de Attila József Nominata.

Mortelmans, Tanja. 2007. Modality in cognitive linguistics. In D. Geeraerts and H. Cuyckens (eds.) The Oxford handbook of cognitive linguistics. Oxford: Oxford University Press. 869-890.

Nagayama, Yukari. 2003. Grammatical outline of Alutor. Kyoto: Endangered Languages of the Pacific Rim.

Nuyts, Jan. 2001. Epistemic modality, language, and conceptualization. Amsterdam \& Philadelphia: John Benjamins.

Oszkó, Beatrix and Larisa Ponomareva. 2010. The morphology of equative in KomiPermyak. Paper presented at Uralic Case, Workshop of the 14th International Morphology Meeting, Budapest, May 15-16, 2010.

Palmer, Frank R. 1999. Mood and modality: Basic principles. In Brown \& Miller (1999, 22).

Palmer, Frank R. 2001. Mood and modality. Cambridge: Cambridge University Press.

Plungjian, Vladimir A. 2003. Obščaja morfologija: vvedenije v problematiku. Moskva: Editorial URSS.

Portner, Paul. 2009. Modality. Oxford: Oxford University Press.

Ralli, Angela. 2010. Compounding versus derivation. In S. Scalise and I. B. Vogel (eds.) Cross-disciplinary issues in compounding. Amsterdam \& Philadelphia: John Benjamins. 57-74.

Ramstedt, Gustaf J. 1957. Vvedenije v altajskoje jazykoznanije. Morfologija. Moskva: Inostrannaja literatura.

Salminen, Tapani. 1997. Tundra Nenets inflection. Helsinki: Suomalais-Ugrilainen Seura.

Scalise, Sergio. 1984. Generative morphology. Dordrecht: Foris.

Sebestyén, Irén N. 1970. Zur juraksamojedischen Konjugation. Finnisch-Ugrische Forschungen 38. 137-225.

Semjonova, Tatjana I. 2004. Kontseptualizatsija emotsionaljnyh sostojanij čerez modus kažimosti. In Germanistika v Rossii. Traditsii i perspectivy. Novosibirsk: Novosibirsk State University. 150-153.

Sorokina, Irina P. and Darja S. Bolina. 2001. Slovarj enetsko-russkij i russko-enetskij. St. Petersburg: Prosveščenije.

Sorokina, Irina P. and Darja S. Bolina. 2005. Enetskije teksty. St. Petersburg: Nauka. http://iling.spb.ru/nord/materia/ency_tit.html (accessed 17 July 2011).

Sovran, Tamar. 1992. Between similarity and sameness. Journal of Pragmatics 18. 329344.

Acta Linguistica Hungarica 61, 2014 
Stassen, Leon. 1985. Comparative and universal grammar. Oxford: Basil Blackwell.

Šentsova, Irina V. 1998. Šorskij glagol. funktsionaljno-semantičeskoje issledovanije. Habilitation thesis. Moscow.

Tereščenko, Natalja M. 1965. Nenetsko-russkij akademicheskij slovarj. Moskva: Sovetskaja entsiklopedija.

Tereščenko, Natalja M. 1973. Sintaksis samodijskih jazykov. Prostoje predloženije. Leningrad: Nauka.

Tereščenko, Natalja M. 1979. Nganasanskij jazyk. Leningrad: Nauka.

Tereščenko, Natalja M. 1982. Nenetsko-russkij i russko-nenetskij slovarj. Leningrad: Prosveščenije.

Tereščenko, Natalja M. 1990. Nenetskij epos: Materialy i issledovanija po samodijskim jazykam. Leningrad: Nauka.

Tereščenko, Natalja M. 2003. Nenetsko-russkij slovarj. St. Petersburg: Prosveščenije.

Tommola, Hannu. 2011. Zametki o sravniteljnyh konstruktsijah (slavjanskije, germanskije i finno-ugorskije jazyki). In V. S. Khrakovskij (ed.) Meždunarodnaja konferentsija, posvjaščonnaja 50-letiju Peterburgskoj tipologičeskoj školy. Materialy i tezisy dokladov. St. Peterburg: Nestor-Istorija. 178-183. http://iling.spb.ru/confs/typo50_2011.pdf (accessed 27 July 2011).

Tsejtlin, Stella N. 1990. Neobhodimostj. In Bondarko (1990b, 142-157).

Tversky, Amos. 1977. Features of similarity. Psychological review 84. 327-352.

Usenkova, Eleonora V. 2002. Renarrativ v nganasanskom jazyke. Linguistica Uralica 38. $50-58$.

Usenkova, Eleonora V. 2007. Subjektiv-Debitiv v nenetskom jazyke. Linguistica Uralica 43. $187-196$.

Verbov, Grigorij D. 1973. Dialekt lesnyh nentsev. In J. N. Popova (ed.) Samodijskij sbornik. Novosibirsk. 4-190.

Vorobjova, Natalja N. 1987. Sravniteljnyje konstruktsii v mordovskih jazykah. Abstract of doctoral dissertation. Tartu.

Wierzbicka, Anna. 1996. Semantics: Primes and universals. Oxford: Oxford University Press.

Wright, Georg Henrik von. 1951. An essay in modal logic. Amsterdam: North-Holland.

Zaliznjak, Anna A. 1992. Issledovanija po semantike predikatov vnutrennego sostojanija. München: Otto Sagn.

Živov, Viktor M. 1998. Formoobrazovanyje. V. N. Jartseva (ed.) Boljšoj entsiklopedičeskij slovarj: Lingvistika. Moskva: Boljšaja Rossijskaja entsiklopedija. 558. 